\title{
PRINCIPAL THREATS TO THE CONSERVATION OF RUNNING WATER HABITATS IN THE CONTINENTAL BIOGEOGRAPHICAL REGION OF CENTRAL EUROPE
}

\author{
MIROSŁAW GRZYBOWSKI* \\ Department of Tourism, Recreation and Ecology, University of Warmia and Mazury in \\ Olsztyn, Oczapowskiego 5, 10-719 Olsztyn, Olsztyn, Poland, ORCID ID: \\ https://orcid.org/0000-0002-1887-7498 \\ *Corresponding author e-mail: grzybomi@uwm.edu.pl
}

Received: $6^{\text {th }}$ June 2020 , Accepted: $20^{\text {th }}$ June 2020

\begin{abstract}
This paper discusses the threats to the running water habitats that are highly important to biodiversity the European Community in the Continental Biogeographical Region (CBR) of Europe, specifically in Poland. This study covers four water course habitat types distinguished in Natura 2000, which is a network of nature protection areas in the territory (3260, 3220, 3240, 3270 - the code of the habitat, as in Annex I of the Habitat Directive), occurring in 806 Special Areas of Conservation in Poland. Based on a multivariate analysis, we found significant differences in the conservation status of running water habitats resulting from a variety of threats, pressures, and activities. Agriculture has a number of negative impacts on running water habitats, which are most evident for the following habitats: 3260 > 3270. Forest management may have both negative (3260) and positive effects on habitats (3270). Natural system modifications strongly affect habitats $3240,3270>3260$. Among the negative anthropogenic influences are pollution (3260>3220); human intrusions, disturbances, and tourism (reported most often) (3260, 3270); transportation and service corridors (3260, and 3270); urbanization, residential, and commercial development tourism (3260); biological resource use other than for agriculture and forestry (3270 > 3260); and mining, extraction of materials, and energy production (3270). Geological events and natural catastrophes - most often inundation - were identified as important hazards for habitat 3240. The development of alien and invasive species strongly affects habitats $3240>3260,3270$, and natural biotic and abiotic processes affect habitats $3220>3260$. Negative impacts associated with climate change were detected mostly for habitat 3260. Taking into account the threats identified, a list of recommended practices for running water habitat types is presented, to be considered in habitat conservation programmes.
\end{abstract}

Keywords: freshwater habitats, threats, biodiversity conservation, Natura 2000

\section{INTRODUCTION}

Running water habitats such as river floodplains are one of the most dynamic ecosystems in Central Europe; may contain a wide array of habitats, from vegetated lowlands to forests to freshwater marshes; and serve important ecological roles for numerous plant and animal species. They fulfil numerous functions in the landscape and their ecological research, 
therefore, has a long tradition (e.g., Tockner \& Stanford, 2002; Pataki et al., 2013; Hein et al., 2016; Blakey et al., 2017; Čuda et al., 2017). These ecosystems harbor unique biodiversity (Schröter et al., 2005; Wilk-Woźniak et al., 2019) and are the most threatened ecosystems worldwide (MEA, 2005). Such systems provide us with many services, such as our drinking water, food, means of transport, and recreational opportunities (Lopoukhine et al., 2012). The ability to preserve biodiversity in Europe's Continental Biogeographical Region (CBR) is usually reduced in current water habitats, represented by degraded river and lake basins (Abell et al., 2019), and their resilience is lower due to human activity (Folke et al. 2004) A review of threats to and conservation challenges faced by global freshwater biodiversity, including running waters, has been the subject of numerous works (MEA 2005; Strayer \& Dudgeon, 2010; Collen et al., 2014; UNEP-WCMC, IUCN 2016; Janssen et al., 2016). We currently face more variable environments with greater uncertainty about how ecosystems will respond to inevitable increases in levels of human use (Folke et al., 2004; Gillson et al., 2019). Changes in ecosystems that may have previously been absorbed may be associated with a loss of resilience caused by the synergistic and combined effects of various pressures. In running water habitats, anthropogenic threats through widespread land cover change, urbanization, industrialization, and engineering schemes like reservoirs, irrigation, and interbasin transfers that maximize human access to water may cause a loss of resilience through such actions as removing response diversity, removing whole functional groups of species, or removing whole trophic levels; impacting ecosystems via waste and pollutant emissions and climate change; and altering the magnitude, frequency, and duration of disturbance regimes (Grzybowski \& Glińska-Lewczuk, 2019).

After centuries of engineering to regulate streams, the direction of river planning changed recently with increasing emphasis placed on ecologically oriented river management (Loucks \& van Beek 2017). The impact of point sources of pollution, such as discharges from production waste, untreated sewage, and other point sources, continues to plague many global waterways, although many countries have implemented stringent regulations to reduce them (Palaniappan et al., 2010). The effects of non-point source pollution are even more widespread and are a challenge even in countries with strong regulations regarding point source pollution (Carpenter et al., 1998). The impact on the hydrological regime; the removal of water from aquifers, rivers, and streams; or direct drainage of a wetland is largely the a consequence of agriculture (Lemly et al., 2000). Aquatic and wetland habitats, according to the recent Red List of European Habitats (Janssen et al., 2016), are mainly threatened by hydrological system alterations; climate change, pollution, and invasive species; and, to a lesser extent, by succession, agriculture intensification, forestry, mining, urbanization (Myronidis et al., 2016), transport, and the overuse of biological resources (Ortmann-Ajkai et al., 2018). Diagnosing the basic threats to water safety, thanks to scientific assessments, in various spatial scales from local to global, aims to ensure the sustainability of water supply systems and to develop intervention scenarios to reverse these trends, including their conventions for the protection of water biodiversity.

The Water Development Report (WWAP, and UN-Water 2018) clearly shows how water is critical to sustainable development. The trend for freshwater biodiversity continues to be downwards, with an $81 \%$ decline in populations of monitored freshwater species between 1990 and 2012 (WWF, 2018), although the world has made appreciable progress in addressing water security issues in some areas with the help of a wide range of solutions (UN Department of Economic and Social Affairs, 2017). Some of the strategies used to address different aspects of water safety either do not benefit freshwater biodiversity or can adversely affect freshwater ecosystems and the species they support (Vörösmarty et al., 2010). The effectiveness of integrated water management strategies depends on striking a balance 
Grzybowski M.: Principal threats to the conservation of running water habitats in the Continental Biogeographical $\underline{\text { Region of Central Europe }}$

between ecosystem protection and human resource use (WWAP \& UN-Water 2018; CBD 2004; UNEP/IPBES 2010; IPBES 2019).

The key issue in environmental management is the change in species composition and its impact on habitats (Balvanera et al., 2006). Worldwide, the development of a protected area network covering a large area is an important conservation activity (Rodrigues et al., 2004; Secretariat of the Convention on Biological Diversity, 2008). Initiatives of coordinated networks of protected areas covering the scale of the continent are extremely difficult to implement. The world's largest multinational coordinated conservation infrastructure is Natura 2000, which stretches across national borders in European Union (UE) (Blicharska et al., 2016). This network provides ecosystem services worth ca. €200-300 billion/year (EC, 2013b). Owing to Natura 2000, it is possible to increase spatial and functional connectivity between unprotected and protected areas and reduce fragmentation, which has been reflected in the of the European Green Infrastructure strategy (Estreguil et al., 2014; Orlikowska et al., 2014). As a system, Natura 2000 stretches across all 27 European Union (EU) countries, including land and sea areas. The aim of the system is to ensure the long-term survival of Europe's most valuable and threatened species and habitats, listed under both the Birds Directive (EC, 2009a) and the Habitats Directive (EC, 1992). According to the European Natura 2000 Barometer (EEA, 2018), the system presently includes 27.758 terrestrial and marine Natura 2000 sites covering $1322630 \mathrm{~km}^{2}$ in total $(18.18 \%$ of the land area) of the European territory. The Birds and Habitats Directives are the cornerstone of EU nature protection policy, protecting over 2000 habitat types, species and habitat of species of community importance. Implementation of the Nature Directives requires continuous work; currently, a number of types of habitats and species are far from acceptable or satisfactory conservation states. This also applies to the tested running water habitats. A number of gaps and challenges have emerged in the nature conservation management system. These gaps have been acknowledged by the EU Biodiversity Strategy to 2020, which calls, among other targets, for the full implementation of the Nature Directives (Target 1) and for the restoration of at least $15 \%$ of the degraded ecosystems (Target 2) by 2020 (EC, 2016). To achieve good functionality of the network, knowledge of the ecological conservation and management issues relevant to Natura 2000 is needed (e.g., the status of species, habitats, and methods for managing the site; provision of environmental education to local communities; strengthening quality control of environmental impact assessment studies) (Popescu et al., 2014). Decline of biodiversity is caused by distortion of natural hydrological regimes, extensive land use, changing forestry and agricultural practices, climate change, and manmade infrastructure disturbing natural ecosystem functionality (Strayer \& Dudgeon 2010). Member States must ensure that the sites are managed in a sustainable manner, both ecologically and economically. It is also important to increase the conversion rate from science to practice and to implement solutions related to the protection of habitats in Member State legislation (Blicharska et al., 2016).

A relatively large portion of the ecological research on the Natura 2000 system is focused on a few (or a single) species within one or a few sites (Orlikowska et al., 2016). Although the Natura 2000 spans across the European continent, the majority of studies have been conducted within regions at the sub-national level (Popescu et al., 2014). Future research on the Natura 2000 should focus on exploring its coherence and relationships between different Natura 2000 areas, examining the adaptability of the system, as well as its relationship to conservation outside the system, to improve evidence-based management and conservation (Davis et al., 2014). Effective conservation requires the involvement of scientists to implement research results into practice (e.g., Cvitanovica et al., 2016), and the inadequate 
distribution of research focuses across the Natura 2000 could limit the achievement of expected conservation outcomes (Hermoso et al., 2017).

The aim of this work is to present the diversity of running water habitat types within the Continental Biogeographical Region (CBR) of Europe in relation to threats, pressures, and activities, as well as their condition and participation in Sites of Community Importance (SCI) and Special Areas of Conservation (SACs) of the Natura 2000 on the national scale of Poland, to indicate directions for correct actions to achieve a favourable conservation status for habitats.

\section{STUDY AREA}

The continental region covers, in whole or in part, the territories of 13 European Union countries (EC 2009b; EEA 2016). These areas include large portions of Poland, Germany, France, Italy, Czechia, and Bulgaria, as well as a significant part of Denmark, Belgium, Luxembourg, Austria, Slovenia, Romania, and Sweden, thereby covering more than one-quarter of the European Union (EU). In Europe, a wide band extends from the west to east, from Central France through the eastern end of Poland in the north and Romania in the south. In the south, it is divided into two almost equal parts, with the steppe plains of the Pannonian region, also including parts of the Adriatic and Baltic coastline and high mountain ranges in the Alpine region. Outside the EU, the continental region stretches to the border with Asia, on the Ural mountains (Fig. 1).

Fig. 1: Study area in the context of the entire continental biogeographical region of Europe

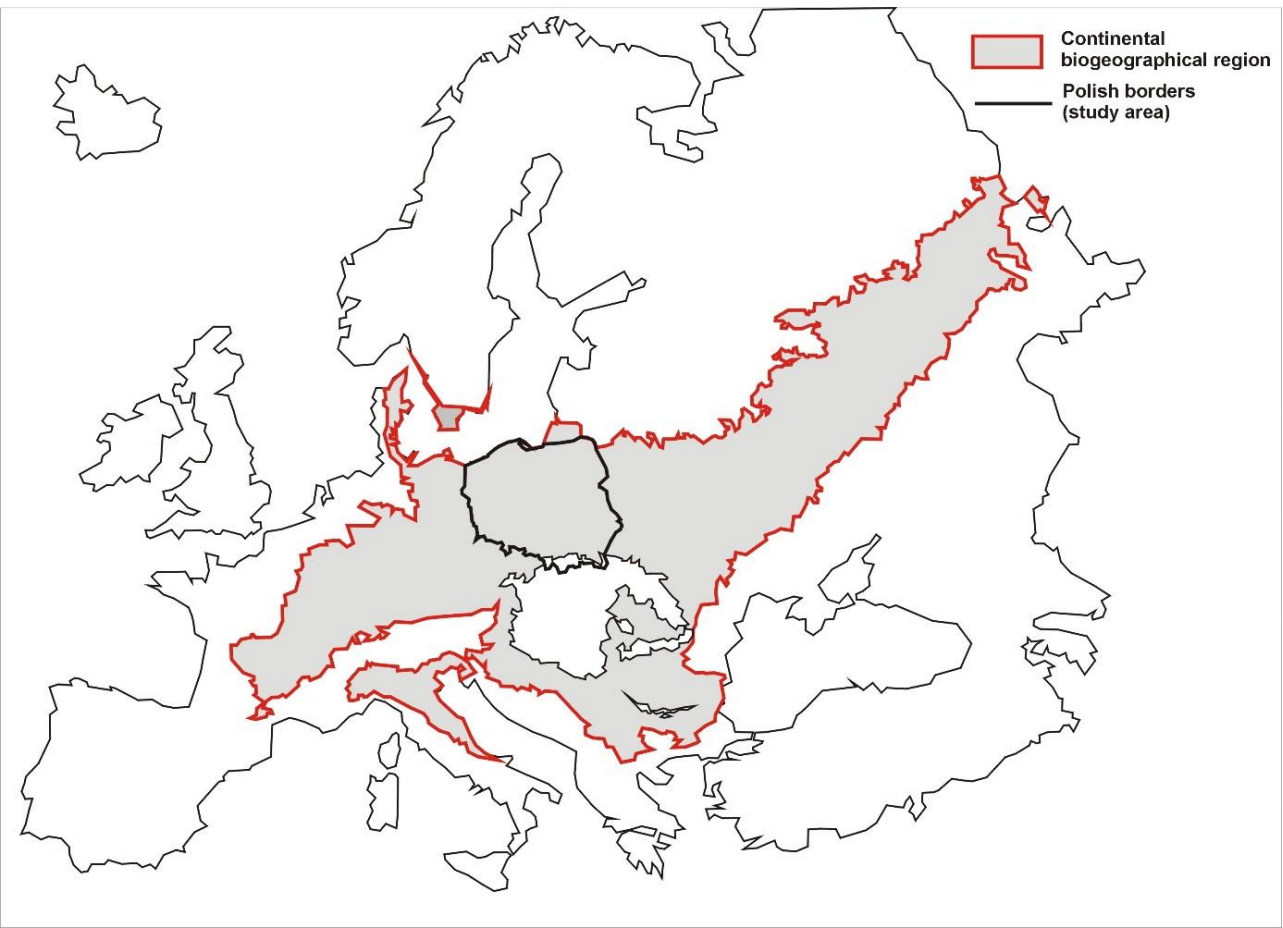


Grzybowski M.: Principal threats to the conservation of running water habitats in the Continental Biogeographical Region of Central Europe

Europe's most important rivers flow through the CBR, such as the Danube, Rhine, Loire, Elbe, Po, Vistula, and the Oder rivers, which have been canalized and regulated, leading to an extensive loss of floodplain habitats and species. Despite these transformations, the CBR is still relatively rich in terms of the biodiversity of its freshwater habitats, including running water habitats (EC, 2009b). The CBR, at the crossroads between many different biogeographical zones, shares many species with other regions (EEA, 2016). Whole areas are dominated by large industrial zones (EC, 2009b), Central Europe was, for many years, the industrial heartland of Europe, providing much of its supply of coal, iron ore, copper, and steel. In terms of human use, population levels are generally high, especially in the northern urban areas of Germany, Poland, and Denmark. According to the European Topic Center on Biological Diversity (European Environment Agency), there are 159 habitat types in the CBR per the Annex I Habitats Directive (EC, 1992), which is the highest of all 9 geographical regions in Europe. Altogether, within the CBR, there are 7.475 Sites of Community Importance (SCIs) under the Habitats Directive and a further 1,478 SPAs under the Birds Directive (EC 2016; EEA 2018). A considerable overlap between some SCIs and SPAs often occurs, which means that the figures are not cumulative. Together, they are estimated to cover more than $10 \%$ of the total land area in this region. Currently, the Natura 2000 in Poland occupies almost 1/5 of the land area of the country, consisting of 849 habitat areas (SCIs) and 145 bird areas (SPAs). This study covered running water habitats occurring in 806 Special Areas of Conservation in Poland in the CBR.

\section{MATERIAL AND METHODS}

\section{Data Collection and Methods}

The overall conservation evaluation of each Natura 2000 site for a habitat includes an assessment of the degree of conservation of the structure and functions, as well as possibilities for restoration (Mróz, 2017). In order to achieve the objectives of this study, the documentation on monitoring Natura 2000 habitats in Poland was analyzed. I considered different data in our analyses of the SACs for the Natura 2000: standard data forms (GDEP, 2018; Eionet, 2018a), management plans (GDEP, 2017; RDEP, 2018), and monitoring by EU Poland SACs (Eionet, 2018b) from three reporting periods from 2009 to 2018 (2009 to 2011, 2013 to 2014, and 2015 to 2018). According to The Interpretation Manual of European Union Habitats-EUR28 (2013), running water habitats include sections of water course habitats with natural or semi-natural dynamics (minor, average and major beds), where the water quality shows no significant deterioration. The survey of the habitat types in Annex I of the Habitats Directive includes running water: 3220 alpine rivers and the herbaceous vegetation along their banks, 3240 alpine rivers and their ligneous vegetation with Salix elaeagnos, 3260 water courses of plain to montane levels with Ranunculion fluitantis and Callitricho-Batrachion vegetation, and 3270 rivers with muddy banks containing Chenopodion rubri p.p. and Bidention p.p. vegetation. My research covered habitats in 7 of the 11 Europe regional biogeographic regions (Table 1) occurring in Poland. In Poland, the studied habitats occurred in both alpine and CBR (Table 2).

The overall assessment of the surveyed types of running water habitats was based on three main parameters: structure and function, future perspective, and range and surface area (Mróz, 2017). The structure includes the physical components of a given habitat type, whereas the assessment of a habitat's functions refers to the ecological processes occurring at a number of temporal and spatial scales and varies greatly between habitat types. Future perspectives indicate the direction of the expected changes in conservation status in the near 
future based on the current status, with the identified pressures, threats, and measures being considered for each of the other three parameters (structure and functions, range, and area). The assessment of the range and surface area must be sufficiently large in relation to favourable reference values. Based on Mróz (2017), the values of the indices for the status of natural habitats, expressed numerically or descriptively, are evaluated on a three-level scale: FV favourable status; U1 unfavourable inadequate; and U2 unfavourable bad (or could be $\mathrm{XX}$ unknown).

Table 1: Overall assessment survey habitats in biogeographical regions in Europe (data source: Eionet 2018a, b)

\begin{tabular}{|c|c|c|c|c|c|c|c|c|c|}
\hline \multirow{2}{*}{ Habitat } & \multicolumn{2}{|c|}{$\begin{array}{l}\text { Special Areas of Conservation in } \\
\text { EU }\end{array}$} & \multicolumn{7}{|c|}{ Biogeographical regions } \\
\hline & $\begin{array}{l}\text { Total habitat } \\
\text { area }\left(\mathrm{km}^{2}\right)\end{array}$ & $\begin{array}{l}\text { Share of the } \\
\text { habitat }(\%)\end{array}$ & ALP & ATL & BOR & $\mathrm{CON}$ & MAC & MED & PAN \\
\hline 3220 & 10595.65 & 1.75 & U1 & $\mathrm{XX}$ & FV & $\mathrm{U} 2$ & $\mathrm{FV}$ & $\mathrm{XX}$ & \\
\hline 3240 & 355.21 & 0.06 & U1 & $\mathrm{XX}$ & & U2 & & XX & \\
\hline 3260 & 2110.07 & 0.35 & U1 & $\mathrm{U} 2$ & $\mathrm{U} 2$ & U1 & & $\mathrm{XX}$ & $\mathrm{U} 2$ \\
\hline 3270 & 327.9 & 0.05 & U2 & U2 & XX & U2 & & U2 & U1 \\
\hline
\end{tabular}

Biogeographical regions: ALP - Alpine, ATL - Atlantic, BOR- Boreal, CON - Continental, MAC - Macaronesia, MED - Mediterranean, PAN - Pannonian; Overall assessment: FV - Favourable, U1 unfavourable inadequate; U2 unfavourable bad. * - Priority feature; Habitat: 3220 Alpine rivers and the herbaceous vegetation along their banks, 3240 Alpine rivers and their ligneous vegetation with Salix elaeagnos, 3260 Water courses of plain to montane levels with the Ranunculion fluitantis and Callitricho-Batrachion vegetation, 3270 Rivers with muddy banks with Chenopodion rubri p.p. and Bidention p.p. vegetation.

Table 2: Occurrence of running water habitats in SACs in Poland (data source: Eionet 2018a,b)

\begin{tabular}{llll}
\hline Habitat & $\begin{array}{l}\text { Number of habitats under } \\
\text { SACs in CBR in Poland }\end{array}$ & $\begin{array}{l}\text { Area covered by habitat type } \\
\text { in the CBR }\end{array}$ & $\begin{array}{l}\text { Share of the habitat area } \\
\text { in Poland }\end{array}$ \\
\cline { 2 - 4 } & & $\mathrm{km}^{2}$ & $\%$ \\
\hline 3220 & 17 & 0.5 & 0.4 \\
3240 & 8 & nd & nd \\
3260 & 104 & nd & nd \\
3270 & 67 & nd & nd \\
\hline
\end{tabular}

Explanation of a habitat code, please see Table 1; *) 28 EU Member States=100\%; nd- no data

\section{Statistical analyses}

The classification threats, pressures, and activities of studied habitats were accepted for the reference list of threats, pressures and activities (final version) (Eionet, 2018a). I analyzed positive and negative impacts on the scale: A - high impact, B-small impact, $\mathrm{C}$ - slight impact, and $\mathrm{X}$-not determined (Eionet, 2018a). The following values were assigned to the intensity of impact: $A=5, B=3, C=2$, and $X=1$. The total measure of impact was determined by multiplying the percentage of the positions of a given impact reference list of threats for habitat by the intensity of interaction.

The statistical analyses were performed on a database consisting of 152 identified threats, pressures, and activities for the nine types of habitats studied (the total number of occurrences was 439). To determine the presence of any relationship between habitat types and threats, pressures, and activities, and to identify the main patterns in the dataset, a principal component analysis (PCA) was performed using CANOCO 5.0 software 
Grzybowski M.: Principal threats to the conservation of running water habitats in the Continental Biogeographical Region of Central Europe

(Microcomputer Power, Ithaca, NY, USA) (ter Braak \& Šmilauer, 1998; Lepš \& Šmilauer, 2014). A preliminary detrended correspondence analysis (DCA) revealed a first gradient length of 3.01 SD; tests conducted prior to the analyses showed that the studied system has an unimodal character, therefore validating the use of unimodal ordination programs (ter Braak \& Šmilauer, 1998; Lepš \& Šmilauer, 2014). Prior to PCA ordination, the data were log-transformed to improve normality. To further understand the dissimilarities between running water habitats based on the threats identified for an individual habitat, we performed hierarchical clustering analysis (HCA) and heat map analysis. HCA is often introduced as a family of techniques to describe and represent the structure of the pairwise dissimilarities amongst objects. We chose a non-specific filtering option with a threshold of the interquartile range $<0.5$ to eliminate all threats with low variability. This enhanced the readability of the heat map. We clustered the points representing rows and columns in the reduced factor space with Euclidean distance by Ward's hierarchical clustering algorithm (ter Braak \& Šmilauer, 1998; Lepš \& Šmilauer, 2014). The advantage of Ward's clustering is that it minimizes the error sum of squares or error variance at each step of clustering. Clustering algorithms and ordination techniques such as PCA are complementary. HCA and the heat map were performed using the XLSTAT ver. 2018.3 software for data analysis and statistical application available for Microsoft Excel ${ }^{\circledR}$ by Addinsoft.

\section{RESULTS}

Only $20.83 \%$ of the surveyed running water habitats in Poland were classified as having a favourable status (FV), whereas $79.17 \%$ were classified as being in an unsatisfactory state (U1 unfavourable inadequate or U2 unfavourable bad; Table 3). The best-preserved habitat types, with a score $>25 \%$ in the FV category in the overall assessment, were in the following decreasing order: $3260>3240$. The most threatened habitats with a score $>30 \%$ in U2 in the overall assessment were $3240>3200$ (Table 3). The structure and function parameters, which are the most susceptible to threat effects, had the highest values in habitats $3260>$ 3240 (>25\% FV, Table 3), whereas the following habitats had the lowest scores: $3220>$ 3240 (>30\% U2, Table 3). The future perspective parameter had the highest values in habitats $3260>3270>3220>3240(>25 \%$ FV, Table 3$)$, and habitats $3240>3200$ had the low value (>30\% U2, Table 3$)$. The range and surface area parameter had the highest values in habitats $3220>3260>3240>3270(>25 \% \mathrm{FV}$, Table 3$)$.

Table 3: The share of a conservation statuses of running water habitats in SACs of CBR in Poland. Data are given in \%

\begin{tabular}{|c|c|c|c|c|c|c|c|c|c|c|c|c|}
\hline & \multicolumn{3}{|c|}{ Structure and function } & \multicolumn{3}{|c|}{ Future perspective } & \multicolumn{3}{|c|}{ Range, surface area } & \multicolumn{3}{|c|}{ Overall assessment } \\
\hline$\overline{\text { Habitat }}$ & $\mathrm{FV}$ & U1 & U2 XX & FV & U1 & U2 XX & FV & U1 & U2 XX & $\mathrm{FV}$ & U1 & $\mathrm{U} 2$ \\
\hline 3220 & & 50.0 & 50.0 & 50.0 & 16.67 & 33.33 & 83.33 & & 16.67 & & 50.0 & 50.0 \\
\hline 3240 & 38.89 & 16.6 & 44.4 & 33.3 & 27.78 & 38.89 & 55.56 & 27.78 & 16.67 & 33.33 & 5.56 & 61.11 \\
\hline 3260 & 83.33 & 8.33 & 8.33 & 100 & & & 58.33 & 33.33 & 8.33 & 50.00 & 33.33 & 16.67 \\
\hline 3270 & & 90.91 & 9.09 & 36.36 & 63.64 & & 36.36 & 63.64 & & & 90.91 & 9.09 \\
\hline Mean & 30.56 & 41.46 & 27.96 & 54.92 & 27.02 & 18.06 & 58.40 & 31.19 & 10.42 & 20.83 & 44.95 & 34.22 \\
\hline
\end{tabular}


The main groups of threats, pressures, and activities identified for running water habitats in SACs of CBR in Poland are presented in Fig. 2. Agriculture (A) has a number of negative impacts on running water habitats, which are most evident for the following habitats: $3260>$ 3270 (Fig.2). Forest management may have both negative (3260) and positive effects on habitats (3270). Natural system modifications (J) strongly affect habitats 3240, $3270>3260$. Among the negative anthropogenic influences are pollution $(\mathrm{H} ; 3260>3220)$; human intrusions, disturbances, and tourism (reported most often) (G; 3260, 3270); transportation and service corridors (D; 3260, and 3270); urbanization, residential, and commercial development tourism $(\mathrm{E} ; 3260)$; biological resource use other than for agriculture and forestry ( $\mathrm{F} ; 3270>3260)$; and mining, extraction of materials, and energy production (C; 3270). Geological events (L) and natural catastrophes - most often inundation-were identified as important hazards for habitat 3240. The development of alien and invasive species (I) strongly affects habitats $3240>3260$, 3270, and natural biotic and abiotic processes $(\mathrm{K})$ affect habitats $3220>3260$. Negative impacts associated with climate change (M) were detected mostly for habitat 3260 .

Fig. 2: Main groups of threats, pressures and activities identified for running water habitats at SACs in the CBR in Poland.

A bubble size is proportional to the number of impacted sites. Numbers of impacted sites are shown on a log-scale (x-axis); Denotations: codes of habitat types - please see Table 1. Main groups of threats, pressures and activities (Eionet 2018a): A - Agriculture; B - Sylviculture, forestry; C - Mining, extraction of materials and energy production; D - Transportation and service corridors; E - Urbanisation, residential and commercial development; F - Biological resource use other than agriculture \& forestry; G - Human intrusions and disturbances; $\mathrm{H}$ - Pollution; I - Invasive, other problematic species and genes; J - Natural system modifications; K - Natural biotic and abiotic processes (without catastrophes); L - Geological events, natural catastrophes; M - Climate change

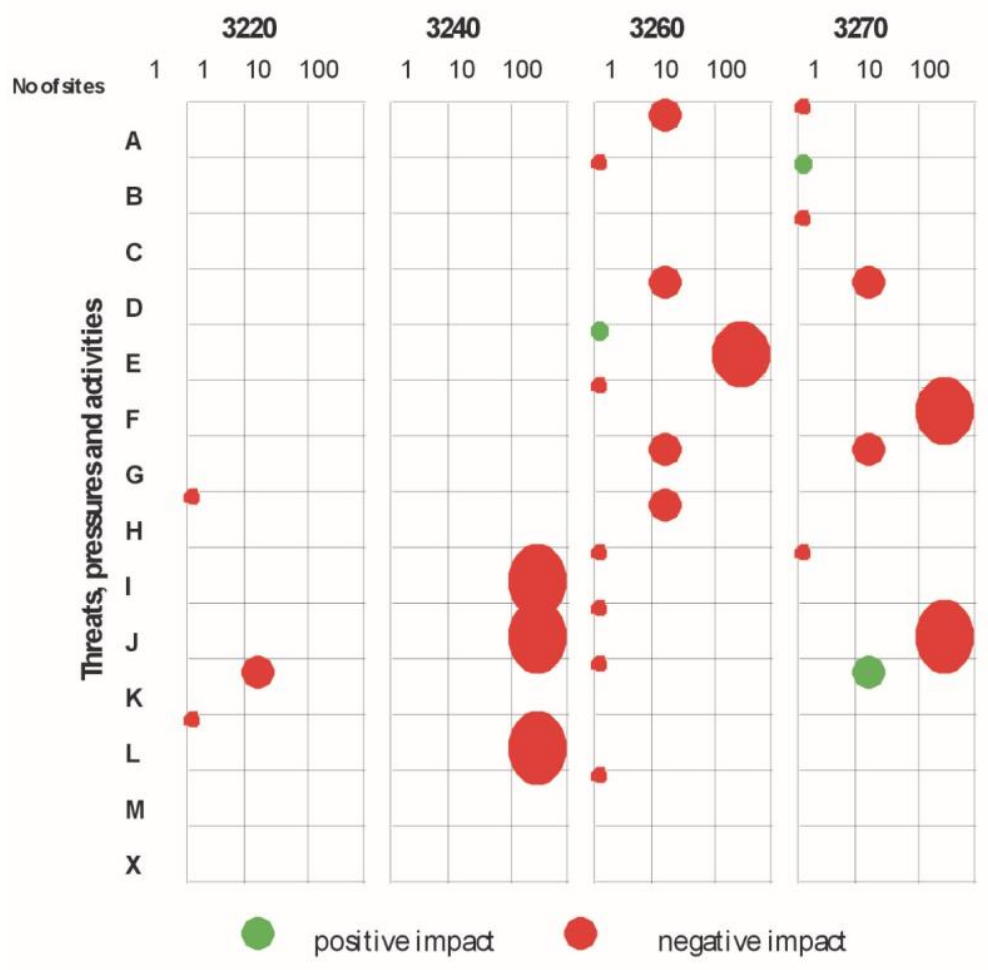


Grzybowski M.: Principal threats to the conservation of running water habitats in the Continental Biogeographical Region of Central Europe

\section{Fig. 3: Biplot of PCA ordination axes for running water habitat types and their threats, pressures and activities.}

Explanation of a habitat code, please see Table 1; Threats (Eionet 2018a): A - agriculture; A01 - cultivation; A02.02 - crop change; A03 - mowing / cutting of grassland; A04 - grazing; A04.01 - intensive grazing; A08 - fertilisation; B - sylviculture, forestry; B02.02 - forestry clearance; C - mining, extraction of materials and energy production; C01.01- sand and gravel extraction; D - transportation and service corridors; D01 - roads, paths and railroads; D01.01 - paths, tracks, cycling tracks; D01.02 - roads, motorways; D01.03 - car parcs and parking areas; D01.04 railway lines, TGV; D01.05 - bridge, viaduct; D03.02 - shipping lanes; D03.02.02 - passenger ferry lanes (high speed); E - urbanisation, residential and commercial development; E01 - urbanised areas, human habitation; E01.01 - continuous urbanisation; E01.02 - discontinuous urbanisation; E01.03 - dispersed habitation; E01.04 other patterns of habitation; E02 - industrial or commercial areas; E02.01 - factory; E03 - discharges; E03.01 disposal of household / recreational facility waste; E03.04 - other discharges; F - biological resource use other than agriculture \& forestry; F01 - marine and freshwater aquaculture; F02.03 - leisure fishing; F04.01 - pillaging of floristic stations; G - human intrusions and disturbances; G01 - Outdoor sports and leisure activities, recreational activities; G01.03 - motorised vehicles; G01.08 - other outdoor sports and leisure activities; G02.10 - other sport/leisure complexes; G05.01 - trampling, overuse; G05.07 - missing or wrongly directed conservation measures; $\mathrm{H}$ - pollution; H01 - pollution to surface waters (limnic, terrestrial, marine \& brackish); H01.05 - diffuse pollution to surface waters due to agricultural and forestry activities; H05.01 - garbage and solid waste; I - invasive, other problematic species and genes; I01 - invasive non-native species; J - natural system modifications; J02 - human induced changes in hydraulic conditions; J02.02 - removal of sediments (mud); J02.03 - canalisation \& water deviation; J02.03.02 - canalisation; J02.04.01 - flooding; J02.05 - modification of hydrographic functioning, general; J02.05.02 - modifying structures of inland water courses; J02.06.06 - surface water abstractions by hydro-energy; J02.08 - raising the groundwater table /artificial recharge of goundwater; J03.03 - reduction, lack or prevention of erosion; K - natural biotic and abiotic processes (without catastrophes); K01.02 - silting up; K02.01 species composition change (succession); K04 - interspecific floral relations; K04.01 - competition; L - geological events, natural catastrophes; L08 - inundation (natural processes); M - climate change; M01.05 - water flow changes (limnic, tidal and oceanic)

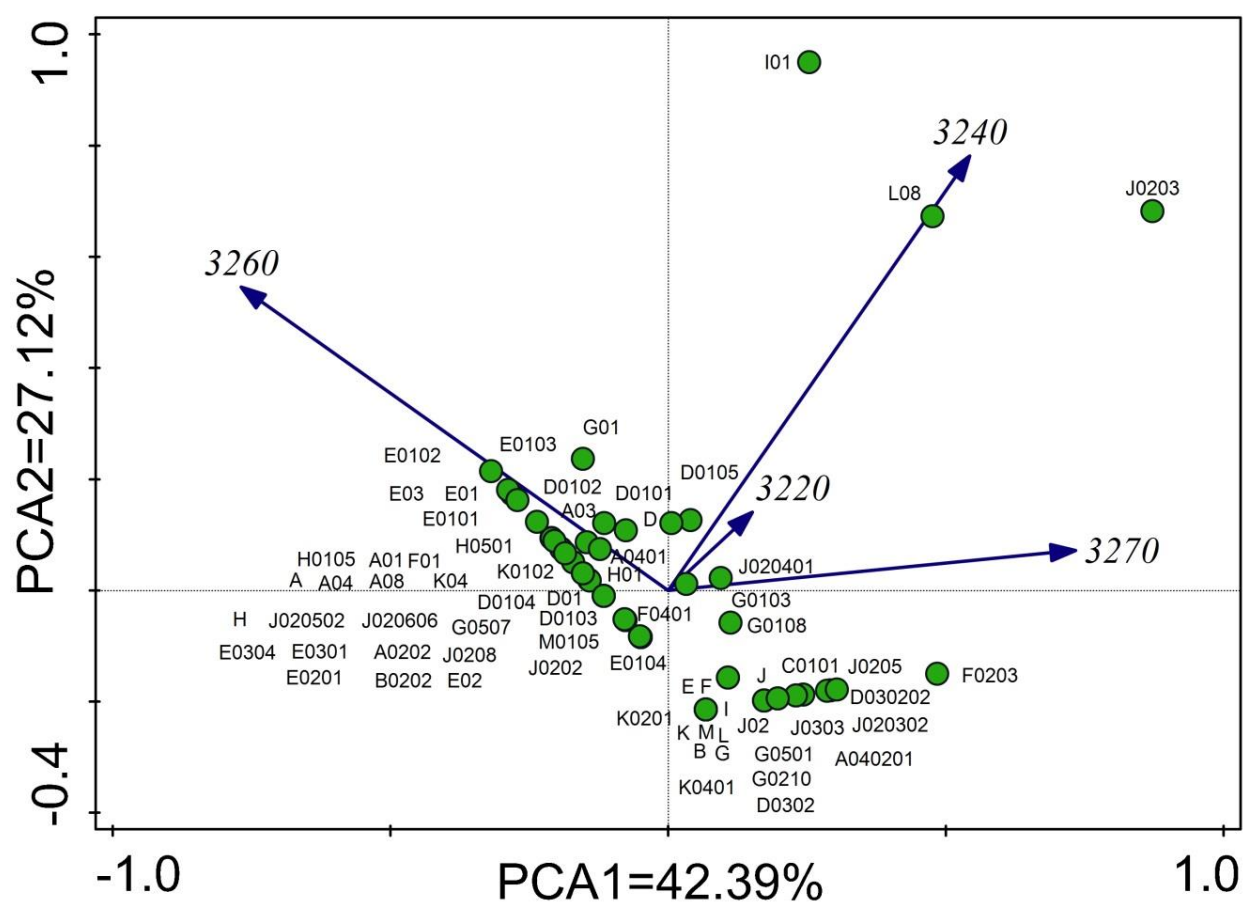


PCA verified the relationship between a given habitat type and its threats, pressures, and activities (Fig. 3). PCA showed that the surveyed habitat types are determined by the first two components against the vectors associated with the various threats. The first (PC1) and second (PC2) PCA components explained $42.39 \%$ and $27.12 \%$ of the total variance, respectively. PC1 showed the highest positive correlation with habitats 3270, 3240 (PC1, $r=0.7330,0.5429$ respectively), and $3220(\mathrm{r}=0.1514)$ and the highest negative correlation with habitat 3260 (PC1, $r=-0.7689)$. PCA2 showed the highest association with habitats $3240(r=0.7816), 3260(r=0.5456)$, and $3220(r=0.1405)$.

The results achieved in the PCA are consistent with the results of a two-way hierarchical cluster analysis (TW-HCA). The heatmap (Fig. 4) visualizes a data matrix with rows and columns ordered according to clustering in the form of hierarchical classification trees of both columns and rows, with "cuts" yielding three clusters of threats and three clusters of habitat types. Among the surveyed running water habitats, a group of two habitat types (3220 and 3240) created a similar cluster in terms of impacted threats and pressures. The other two habitats (3260, and 3270) created individual clusters.

The main threats affecting the cluster of habitat 3260 water courses with plain to montane levels of Ranunculion fluitantis and Callitricho-Batrachion vegetation (Fig. 4) are anthropogenic (A08, H01, H01.05, H05.01, and E03, E03.01, E03.04) eutrophication, caused by the transfer of nutrients from catchments significantly influenced by agricultural activities (A01, A02.02, A03, A04, A04.01), urbanized areas (E01.01, E01.02, E01.04, E02, E02.01), transportation (D, D01, D01.01, D01.02, G01.03), including railway lines (D01.04), bridges, viaducts (D01.05), and parking areas (D01.03), and, to a lesser extent, natural interactions, e.g., interspecific floral relations (K04) due to missing or wrongly directed conservation measures (G05.01) and also because of the pillaging of floristic stations (F04.01) (Fig. 4). The threats attributed to the cluster of fluvial habitats (3260; Fig. 4) are mainly related to human-induced natural system modifications $(\mathrm{J})$ through changes in hydraulic conditions (J02.02, J02.05.02, J02.06.06, J02.08), mainly the improper modification of hydrographic functioning. The negative pressure on these habitats is also caused by water flow changes (M01.05) due to climate change.

The threats attributed to the cluster, including habitat 3270 rivers with muddy banks and Chenopodion rubri p.p. and Bidention p.p. vegetation (Fig. 4), are mainly related to human-induced natural system modifications $(\mathrm{J})$ through changes in hydraulic conditions (J02), mainly through the improper modification of hydrographic functioning (J02.03.02, J02.05), including flooding modifications (J02.04.01) and the reduction, lack, or prevention of erosion (J03.03) (Fig. 4). The threats caused by agricultural activities (A), particularly those involving non intensive grazing (A04.02.01), sand and gravel extraction (C01.01); human intrusions, disturbances, and tourism (reported most often) (G, G01.08, G02.10, G05.01); and leisure fishing (F02.03), as well as roads (D01) and railway lines (D03.02, D03.02.02) are also important for habitats.

The threats attributed to the cluster of fluvial habitats (3220, 3240; Fig. 4) are mainly related to human-induced natural system modifications $(\mathrm{J})$ through changes in hydraulic conditions, predominantly the improper modification of hydrographic functioning including canalization and water deviation (J02.03). The disappearance of natural processes results from a lack of flood impacts (L08), such as abiotic (slow) natural processes (K01.02 silting up, K02.01 species composition changes, and succession) and interspecific floral relations (K04.01). The negative pressure on these habitats is also caused by the incursion of invasive non-native species (I01). 
Grzybowski M.: Principal threats to the conservation of running water habitats in the Continental Biogeographical Region of Central Europe

Fig. 4: Two-way hierarchical cluster analysis (TW-HCA) exposing relationship between clusters of running water habitats and the threats, pressures and activities. Heat map colours indicate minimum (yellow) to maximum (red) relationship gradient between running water habitats and threats, pressures and activities. Codes of habitats and threats - please see Fig. 3

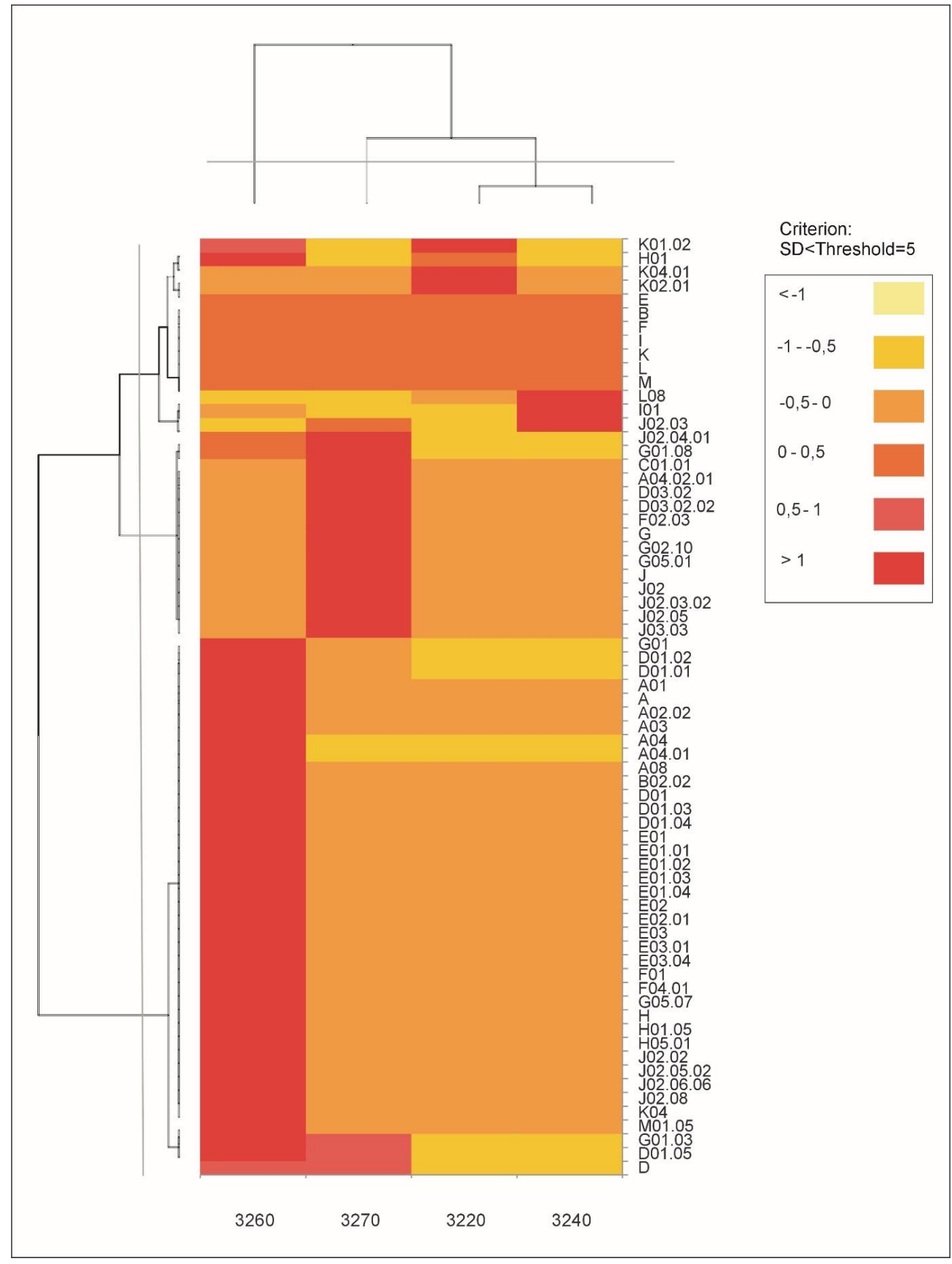




\section{DISCUSSION}

Activities for the protection of biodiversity should be adapted to biogeographic conditions (Gustafsson et al., 2015); the approach to the problem presented in the paper is a response to this need, completing the rare group of studies pertaining to larger spatial scales. Small- or even regional-scale actions may have negative consequences for the conservation of species and habitats that are dependent on large-scale patterns and processes, which have become increasingly prominent in recent years (Rattisab et al., 2018) but remain underutilized in Natura 2000 (Orlikowska et al., 2016). Moreover, such an approach would be consistent with the conservation biogeography framework (Kreft \& Jetz, 2010) and would foster more cross-scale cooperation in the practical management of the system, a process that is necessary for attaining conservation goals in large-scale initiatives (Gustafsson et al., 2015).

\section{The Loss of Running Water Habitats}

Habitat loss has been the greatest threat to freshwater biodiversity (Č́ižková et al., 2013; Zorilla-Miras et al., 2014; Hein et al., 2016, WWF, 2018). Land-use change is a key driver of the loss of habitats (MEA 2005; Janssen et al., 2016). It contributes to global change and significantly affects the structure and functions of ecosystems (Foley et al., 2005; Amici et al., 2015). Landscapes have changed dramatically in the last 50 years as a result of a combination of factors, including human population growth and rapid technological advancement (Lepers et al., 2005; Freudenberger et al., 2013; Amici et al., 2015, Ustaoglu \& Williams, 2017). Similar phenomena, such as urbanization and residential and commercial development, have directly and indirectly affected the catchment areas of the studied running water habitats, such as 3260 and 3270 . Biodiversity losses induced by changes in land use are driven not only by urban sprawl and agricultural intensification but also by abandoning traditional rural landscapes, which leads to the initiation of natural succession (Agnoletti, 2014). The development of rural areas located far from city boundaries, including uncontrolled development of the land, was observed as part of a study of habitat catchments 3260 (Figures 3 and 4). This trend was observed even in regions with decreasing populations outside Poland, notably in Italy and Eastern Germany (Ustaoglu \& Williams, 2017).

Rapid ecosystem change, from natural ecosystems to cultural landscapes, challenges the adaptive capacity of local environmental and especially freshwater ecosystems (Fernández-Llamazares et al., 2015). Negative impacts on the conservation statuses of the examined habitats 3260 and 3270 were caused by transportation and service corridors (including parking areas - threats to habitat 3260) and railway lines (3260). The main effects of roads on biodiversity and ecosystems can be summarized as follows: an increase in the density of the road network results in fragmentation of habitats, and it can lead to their total loss and intensification of the impact of barrier effects (Underhill \& Angold 2000; Freudenberger et al., 2013); the intensification in traffic affects the diversity of organisms through pollution, noise, artificial lighting and other direct impacts (Parris \& Schneider, 2009; Selva et al., 2011); the impact is on larger landscape scales within the "road-effect zone", where there is a buffer effect resulting from increased traffic, which impacts biodiversity (Eigenbrod et al., 2009; Freudenberger et. al., 2013).

In recent years there has been homogenization and the synchronized management of activities in mosaic cultural landscapes, which has resulted in a reduction in the diversity of land use (Grzybowski, 2014). Management practices have contributed to a reduction in the wealth of semi-natural components. In this study, the poor management of forms of nature conservation and missing or wrongly-directed conservation measures were indicated for habitat 3260 (Fig. 4). In those cultural landscapes where agricultural practices have retained the largest number of "traditional" attributes, in which lifestyle and culture are often retained, 
Grzybowski M.: Principal threats to the conservation of running water habitats in the Continental Biogeographical Region of Central Europe

there is a high number of species and especially diversity of habitats (Maffi \& Woodley, 2010; Babai et al., 2015).

Intensive grazing and cultivation in the catchment area appear to be the cause of the poor condition of habitat 3260 (Fig. 4.), and non-intensive grazing appears to be the cause of the poor condition of habitat 3270 . Notably, to maintain landscape heterogeneity, it is beneficial to have a variety of forms of management, which helps to maintain a dynamic balance between ecological processes and multiple human activity (Pretty et al., 2009). The reintroduction of grazing in river catchments corresponds to the restoration of surrogate ecological processes, increases the range of agriculture, but prevents the introduction of its intensive forms (Sandom et al., 2013). There is an increasingly urgent global imperative to know and protect both cultural and biological diversity, and previous studies (Amici et al., 2015; Babai et al., 2015) have confirmed that similar policy adjustments are key to conserving cultural landscapes, with traditional agriculture and lifestyles that have evolved under the local environment but also the rich biological heritage of European landscapes.

\section{The Biodiversity of Running Water Habitats}

Changes in biocenosis evolution, succession, and plant species composition were indicated in the studied fluvial habitats 3260 and 3220 (Figs 2-4). The stability of river habitats is directly related to their hydroperiods, which refers to the seasonal shift in the surface and sub-surface water levels. The mosaic of numerous aquatic habitats maintains high biodiversity (Grzybowski \& Glinska-Lewczuk 2019), and succession is the main natural process in floodplains (Ortmann-Ajkai et al., 2018)..The biodiversity of floodplain ecosystems is threatened by numerous factors, such as drainage, water regulation, the pervasiveness of dams, levees (Tockner and Stanford, 2002; MEA 2005; Čížková et al., 2015), and land use changes, causing cumulative alterations in hydrologic connectivity within the greater landscape (Zorilla-Miras et al., 2014; Hein et al., 2016), overexploitation aquifers (Harrison et al., 2010), atmospheric deposition and chemical pollution from neighboring agricultural land (Glińska-Lewczuk 2005, Blackwell \&Pilgrim, 2011; Grzybowski 2014; Hein et al., 2016), the rapid spreading of non-native species (Hein et al., 2016), and global climate change (Tockner and Stanford, 2002; Č́ížková et al., 2015).

Significant threats to running water habitats in the CBR have resulted from human-induced changes in hydraulic conditions that have modified entire natural systems. A negative impact on the conservation status of habitats occurred in habitats 3240, 3260, and 3270 (Figs 2-4). Flood protection is high on political agendas worldwide, especially since climate change is projected to increase the frequency, severity, and extent of floods (Auerswald et al., 2019). Related regulatory issues, such as riverbed incision, lowering of the groundwater level, and changes in the land use of the catchment, are commonly reported as the main causes of the loss of biodiversity in flood-prone areas (e.g. Hein et al., 2016; Janssen et al., 2016).

The loss of running water species and habitats is mainly caused by the simplification and channelization of rivers and associated floodplain habitats (Hajdukiewicz et al., 2017). Such interactions are indicated mainly for habitats 3260 and 3270 (Fig. 4). The mosaic of habitats, differing not only in productivity and diversity, abundance, composition, and subsequent states of fauna and flora but also humidity and sediment properties, are affected by flooding modifications (Hefting et al., 2013). The flooding modifications indicated were shown to be an indirect threat to all habitats except 3220 and 3240 (Fig. 4 ) Most floodplains in Europe have degraded due to reduced hydromorphological dynamics. This has led, among other things, to a decrease in the habitat types that are an essential part of floodplains (Percic et al., 2009). Human impact has significantly changed habitat conditions in active floodplains, by 
damming rivers, training rivers, disconnecting floodplains, chemical pollution and fertilizer pollution, introduction of invasive species, or by intense forestry (e.g., Schnitzler et al., 2005; Mitsch et al., 2012).

A negative effect on phytodiversity in ditches due to nutrient input by the fertilization of adjacent meadows was observed by Müller et al., (2016). The pollution of surface waters, reported as the cause of the poor conservation status of the habitats, was indicated for habitat 3260, whose watercourses were poorly managed (Fig. 4). Ditches not only have a separate species composition but also provide important habitats for rare species and species important for conservation; this depends on the intensity and frequency of maintenance as well as the heterogeneity of humidity and the successive stage of the ditch (Garniel, 2000), which affects the protection status of water courses (Grzybowski, 2014). The strong impact of the temporal diversity of disturbances, mowing frequency, and time on species composition has been well-studied (Hobbs \& Huenneke, 1992; Meier et al., 2017) and has been highlighted as especially relevant for regional species diversity in agricultural landscapes (Meier et al., 2017). Therefore, the scope, frequency, and type of maintenance work on the drainage network affect the condition of the examined aquatic habitats that are important for the EU. Partial cleaning of the ditches, or half-site cleaning, irregular cleaning with differences in timing, (Garniel, 2000), and a cleaning frequency of two to three years (Van Strien et al., 1991), have also been shown to maximize phytodiversity at a local scale, and because nitrogen accumulates especially in irrigation ditches, biomass removal after mowing can be beneficial for species sensitive to nutrient-rich conditions. -

\section{Biological Invasions}

Biological invasions, together with loss and habitat disturbances, are among the leading causes of biodiversity decline in inland aquatic habitats (Rodríguez-Merinoa et al., 2018). Since the early 1990s, the number of non-native aquatic plant species in Europe has increased (Keller et al., 2011). Species introductions are rapidly changing the composition of freshwater habitats worldwide (see Havel et al., 2015; Sardain et al., 2019). This leads to habitat alterations and can create invasion opportunities, which can transform natural habitats and thus create new niches, a process that facilitates the establishment of various non-native aquatic species (Zedler \& Kercher, 2004). Humans are vectors for these species in a highly globalized world; the lack of barriers allows their numbers to continually increase (Havel et al., 2015; Strayer, 2010). The accumulation of materials in wetlands provides invaders with the resources they need to form monotypes, which makes them particularly vulnerable to invasion (Zedler \& Kercher, 2004). Threats of invasive and other problematic species were not frequently reported in the studied habitats - only in habitats 3240 and 3260 (Fig. 4). Although the present invasion level is relatively low, the early detection of their localities is essential to eliminate them as sources of reproduction. The following species were identified in the littoral zone of the habitats studied: Fallopia spp., Heracleum mantegazzianum, Impatiens glandulifera, and Solidago spp., which, in protected areas in Poland and the Czech Republic (Braun et al., 2016; Vardarman et al., 2018), pose a significant threat to the conservation of biological diversity. The rate of the spread of the invasion of non-indigenous species and indigenous species is affected by many factors that differ along temporal and spatial scales. Such factors include resource availability, climate and local weather patterns, vegetation growth and development processes, the number of species present in secondary regions, propagule pressure, and competition, disease, and adaptation, constituting related ecosystem processes (Vardarman et al., 2018). Long-distance seed dispersal along communication routes has long been recognized as a typical, rather than infrequent, phenomenon (Von Der Lippe \& Kowarik, 2007; Schurr et. al., 2009). A positive relationship 
Grzybowski M.: Principal threats to the conservation of running water habitats in the Continental Biogeographical Region of Central Europe

between the proximity to streams has also been confirmed as well as the occurrence of Invasive Alien Species (IAS) (Catford et al., 2011; Richardson et al., 2007; EEA 2012), especially for I. glandulifera (Čuda et al., 2017) and Fallopia spp. (Mandák et al., 2004). Streams and rivers act as spreading vectors for alien species, and these species have a strong preference for such habitats. The problem of the growing number of foreign alien neophytes occurring in and around man-made habitats should be addressed through prevention, early detection, and rapid response efforts, and the fight against invasions in Special Areas of Conservation should be strengthened through proper management of them (Lososová et al., 2006; Lambdon et al., 2008). Habitat suitability models that have been used to determine the locations most threatened from invasive alien species and select these areas for regular monitoring should be used to solve the problem (Vardarman et al., 2018).

\section{Climate Changes}

Multiple studies published in scientific journals show that the Earth's climate is warming and will continue to warm at an increasingly rapid pace. Most of the leading scientific organizations worldwide have issued public statements endorsing this position (Wuebbles et al., 2017, Royal Society, 2017). The impact of climate change is difficult to assess, and these impacts extend well beyond an increase in temperature, affecting ecosystems and communities around the world. Some of the damaging effects are already clear and likely to increase (Janssen et al., 2016; Molina-Navarro et al., 2018). These include floods and droughts, which were indirectly observed in our study (Fig. 4). However, the direct relationship between the poor conservation status of the habitats in the collected data was associated only with habitat 3260 (Figs 2-4).

Threats of extremely rare or until now non-existent phenomena in specific areas may be caused by changes in the composition, frequency, and intensity of individual components of the environment that arose as a result of climate change (Morelli et al., 2016).. Climate change is predicted to further impact ecosystems by causing changes in species, phenology, ranges, and community composition (Chen et al., 2011). An increasing problem for the water-dependent habitat CBR in Europe is the reduction in groundwater levels resulting from natural- and human-induced hydrological modifications and climate change. The same factors are also responsible for the degradation of floodplain systems, particularly riverbed incisions and floodplain aggradation (Pataki et al., 2013). Despite the diversity of solutions that can be implemented to replenish water resources or slow down and even reset the degradation of aquatic ecosystems, other co-existing factors may still pose threats. Therefore, processes and phenomena in complex water-based systems should be strengthened through complex management measures to mitigate and reduce anthropogenic threats.

\section{CONCLUSIONS}

The global decline in biodiversity occurring at a much faster rate in aquatic than in most land systems (Vaughn, 2010) is a vector of many human-generated threats and pressures in flowing waters that have been identified by this study. Running water is of major economic significance for settlements, subsistence and commercial agriculture, and fisheries and tourism, the fluxes of which are weakening mechanisms of control. Running water habitats require considerate and integrated approaches and sustainable management of their natural resources, considering all their functions: natural, landscape, social, and economic. The modern concept of the conservation of biological diversity assumes complex measures that are aimed not only at protecting exceptionally valuable and relatively large sites included in 
specially protected natural areas but also small sites, including land for economic use. Its goal is to balance knowledge and action, because often problems related to protection are social and economic, not scientific. Under the conditions of exceptionally high anthropogenic impact on aquatic ecosystems, increasing control over land use in agricultural, forest, urbanized, and recreational catchment areas as well as its form of use is an urgent protective task in all CBR areas in Europe. The EU Water Framework Directive (WFD) has not delivered on its main objectives for the non-deterioration of water status and the achievement of a good status for all EU waters; almost $50 \%$ of European water bodies are failing to achieve the environmental objectives established by the WFD in 2016 (Voulvoulis et al., 2017). To ensure the future sustainable use of freshwater wetland systems, the implementation of the multiple directives controlling ecosystem services, biodiversity, and cultural heritage needs to be harmonized. For any activity that takes place in a river basin and has impacts downstream, actions are needed to enhance catchment-level and cross-sectional cooperation among different administrative and operational actors and institutes, such as public administrations implementing the WFD, the general and regional directorates for environmental protection involved in implementing Habitat and Bird directives, non-governmental organizations (NGOs), and the private sector. This offers the means to balance the competing demands of different users of the same resources and to manage the resources sustainably. The cause of the identified pressures and threats revealed in the study may be low effectiveness of applying the law on nature protection in Poland. Polish regulations largely result from the implementation of European Community law, recognizing that aquatic ecosystems are beneficial for human beings. This is apparent in spatial management, nature conservation, water management, agriculture, and forestry; however, implemented rules at national level are not harmonized with each other (Stępniewska et al., 2018). The inclusion of nature protection measures in national economic development programs so far at both governmental and social levels seems insufficient. Regulations that allow for the adjustment of existing legal tools are urgently required, by implementation of planning processes involving various partners, appropriate management of results of scientific studies, and strengthening of institutional potential. This should limit the impact of existing pressures on running water habitats and contribute to preservation and improvement of habitats and their functions.

In order to reduce anthropogenic threats and pressures, it is necessary to implement management measures to strengthen natural processes and phenomena in complex water-based systems. We found it extremely important to mimic the natural flow regime because it influences aquatic biodiversity via several interrelated mechanisms that operate over different spatial and temporal scales (Bunn \& Arthington, 2002). Taking the above into account, as well as the relevant literature, we compiled a list of practices (Table 4) supporting the conservation of running water habitats in reference to the recognized threats. 
Grzybowski M.: Principal threats to the conservation of running water habitats in the Continental Biogeographical Region of Central Europe

\section{Table 4: A list of recommended of conservation practices in the direct and indirect surroundings of running waters habitats (per Grzybowski \& Glińska-Lewczuk 2019; modified)}

\begin{tabular}{|c|c|c|c|c|c|}
\hline Conservation practice & \multicolumn{4}{|c|}{ Habitat code } & References \\
\hline $\begin{array}{l}\text { The aim is to reduce nutrient and sediment runoff that reaches the } \\
\text { water: } \\
\text { reduce arable land; restore grassland; increase the presence of } \\
\text { meadows. }\end{array}$ & $\mathrm{x}$ & $\mathrm{x}$ & $\mathrm{xx}$ & $\mathrm{x}$ & $\begin{array}{l}\text { Naiman \& Decamps 1997; } \\
\text { Beltran et al., 2011; } \\
\text { Leyssen } \text { et al., 2014; } \\
\text { Toporowska } \text { et al., 2018; } \\
\text { Hermoso et al., 2018; }\end{array}$ \\
\hline $\begin{array}{l}\text { Maintain low concentrations of nutrients (nitrogen and phosphorus) } \\
\text { and calcium, low electrolytic conductivity, keep high transparency } \\
\text { and low colour that allow the existence and development of } \\
\text { vegetation lobelia, Chara spp.; manage unpaved roads }\end{array}$ & $\mathrm{x}$ & $\mathrm{x}$ & $\mathrm{xx}$ & $\mathrm{x}$ & $\begin{array}{l}\text { Naiman \& Decamps 1997; } \\
\text { Roni et al., 2008; Beltran et } \\
\text { al., 2011; Goode et al., } \\
\text { 2012; Wilk-Woźniak et al., } \\
\text { 2019; }\end{array}$ \\
\hline $\begin{array}{l}\text { Implement agricultural best management practices and good } \\
\text { agricultural practices recognised on the national or international } \\
\text { level (FAO, EU Nitrates Directive, etc.); location - some } \\
\text { sub-catchments or even stream reaches may support higher priority } \\
\text { freshwater biodiversity elements and ecosystem processes than } \\
\text { others, but most terrestrial PAs have not been sited with these } \\
\text { elements in mind }\end{array}$ & $\mathrm{x}$ & $\mathrm{x}$ & $\mathrm{x}$ & $\mathrm{x}$ & $\begin{array}{l}\text { Ellison et al., 2009; Herbert } \\
\text { et al., 2010; Zedková et al., } \\
\text { 2014; Thieme et al., 2016; } \\
\text { Hermoso et al., 2018; Abell } \\
\text { et al., } 2019\end{array}$ \\
\hline $\begin{array}{l}\text { Exclude livestock from streams, reduce grazing intensity, and } \\
\text { provide livestock with alternative water sources }\end{array}$ & $\mathrm{xx}$ & $\mathrm{xxx}$ & $\mathrm{xxx}$ & $\mathrm{xxx}$ & $\begin{array}{l}\text { Ellison } \text { et al., 2009; } \\
\text { Leyssen } \text { et al., 2014; } \\
\text { Sievers } \text { et al., } 2017\end{array}$ \\
\hline Maintain green zones in and around urbanized areas & & & $\mathrm{xx}$ & & $\begin{array}{l}\text { Gold et al., 2019; } \\
\text { Wilk-Woźniak et al., } 2019\end{array}$ \\
\hline Maintain proper water and sewage management & $\mathrm{x}$ & $\mathrm{x}$ & $\mathrm{xx}$ & $\mathrm{x}$ & $\begin{array}{l}\text { Ostrofsky 1978; Gold et al., } \\
2019\end{array}$ \\
\hline Keep water as a living part of urbanized areas & $\mathrm{xx}$ & $\mathrm{xx}$ & $\mathrm{xxx}$ & $\mathrm{x}$ & $\begin{array}{l}\text { Beltran } \text { et al., 2011; } \\
\text { Leyssen } \text { et al., 2014; } \\
\text { Doulgeris, and Argyroudi } \\
\text { 2018; Abell } \text { et al., } 2019\end{array}$ \\
\hline $\begin{array}{l}\text { Properly manage mines and excavations so as to not to destroy } \\
\text { hydrological conditions }\end{array}$ & $\mathrm{xxx}$ & $\mathrm{XXX}$ & & & $\begin{array}{l}\text { Cravotta } \text { et al., 2013; } \\
\text { Nielsen, and Kelly 2016; } \\
\text { Worku 2017; Sheridan } \text { et } \\
\text { al., 2018; }\end{array}$ \\
\hline
\end{tabular}


Journal of Landscape Ecology (2020), Vol: 13 / No. 2

\begin{tabular}{|c|c|c|c|c|c|}
\hline Prohibit the creation of mines and excavations & $\mathrm{xxx}$ & $\mathrm{XxX}$ & & & $\begin{array}{l}\text { Kapustka } \text { et al., 2016; } \\
\text { Worku } 2017\end{array}$ \\
\hline $\begin{array}{l}\text { Remove vegetation from the bottom and slopes of water reservoirs } \\
\text { (mow rushes, remove plant biomass) }\end{array}$ & $\mathrm{xxx}$ & $\mathrm{xxx}$ & $\mathrm{xx}$ & $\mathrm{xx}$ & $\begin{array}{l}\text { Güsewell \& Le Nédic 2004; } \\
\text { Strayer, and Dudgeon } \\
\text { 2010; Leyssen } \text { et al., 2014; } \\
\text { Francis } \text { et al., 2019; } \\
\text { Franklin } \text { et al., 2019; } \\
\text { Harvey et al., 2019; }\end{array}$ \\
\hline Prohibit fisheries & & & $\mathrm{x}$ & & Wilk-Woźniak et al., 2019 \\
\hline $\begin{array}{l}\text { Mitigate climate change (manifesting itself largely through } \\
\text { hydrological impacts) }\end{array}$ & $\mathrm{x}$ & $\mathrm{x}$ & $\mathrm{xx}$ & $\mathrm{x}$ & $\begin{array}{l}\text { Folke } \text { et al., 2004; } \\
\text { Kingsford, 2011; Goode } \text { et } \\
\text { al., 2012; Creed } \text { et al., } \\
\text { 2018; }\end{array}$ \\
\hline $\begin{array}{l}\text { Mitigate the outcomes, threats outside the borders of a protection } \\
\text { area (e.g., dams, water withdrawals, agriculture, mining, forestry, or } \\
\text { urbanization) can impinge upon the ecosystems and species within } \\
\text { them; spatial scale - small protected areas may have little impact, } \\
\text { although if they drain to or comprise small headwater streams, the } \\
\text { impact may be proportionately greater than if they are located } \\
\text { further downstream in river networks }\end{array}$ & & & $\mathrm{xxx}$ & & $\begin{array}{l}\text { Folke } \text { et al., 2004; Leyssen } \\
\text { et al., 2014; Díez et al., } \\
\text { 2015; Hermoso } \text { et al., 2016; } \\
\text { Genseberger } \text { et al., 2016; } \\
\text { Thieme et al., 2016; } \\
\text { Doulgeris \& Argyroudi } \\
\text { 2018; Abell et al., 2019; } \\
\text { Biró } \text { et al., 2018; }\end{array}$ \\
\hline $\begin{array}{l}\text { Prohibit afforestation - many but not all studies of afforestation, i.e., } \\
\text { planting tree stands where there were none previously, focus } \\
\text { on plantation forestry, looking primarily at the impacts of } \\
\text { afforestation with non-native (typically conifer) species on stream } \\
\text { chemistry }\end{array}$ & & & $\mathrm{x}$ & & $\begin{array}{l}\text { Friberg } \text { et al., } 1998 \\
\text { Tierney } \text { et al., } 1998 \\
\text { Sievers } \text { et al., } 2017\end{array}$ \\
\hline $\begin{array}{l}\text { Reforestation - it may be assumed that on balance the impacts of } \\
\text { reforestation using native species should be positive for freshwater } \\
\text { biodiversity in the long term; }\end{array}$ & & & $\mathrm{xxx}$ & & $\begin{array}{l}\text { Leyssen } \text { et al., 2014; } \\
\text { Filoso } \text { et al., 2017; Yeung } \\
\text { et al., } 2017\end{array}$ \\
\hline Consider cumulative anthropogenic impacts & & & $\mathrm{xX}$ & & $\begin{array}{l}\text { Beltran } \text { et al., 2011; Bloom } \\
\text { et al., 2013; Hein } \text { et al., } \\
\text { 2018; Abell et al., 2019; } \\
\text { Wang et al., } 2019\end{array}$ \\
\hline
\end{tabular}

For explanation of habitat codes, please see Table 1; note: $\mathrm{xxx}$ - very important; $\mathrm{xx}$ - important; $\mathrm{x}$ - favourable.

\section{ACKNOWLEDGEMENTS}

This research did not receive any specific grant from funding agencies in the public, commercial, or not-for-profit sectors.

\section{REFERENCES}

Abell, R., Vigerstol, K., Higgins, J., Kang, S., Karres, N., Lehner, B., Sridhar, A. \& Chapin, E. (2019). Freshwater biodiversity conservation through source water protection: Quantifying the potential and addressing the challenges. Aquat Conserv https://doi.org/10.1002/aqc.3091 
Grzybowski M.: Principal threats to the conservation of running water habitats in the Continental Biogeographical Region of Central Europe

Agnoletti, M. (2014). Rural landscape, nature conservation and culture: some notes on research trends and management approaches from a (southern) European perspective. Landsc. Urban Plan. 126, 66-73. https://doi.org/10.1016/j.landurbplan.2014.02.012

Amici, V., Landi, S., Frascaroli, F., Rocchini, D., Santi, E. \& Chiarucci, A. (2015). Anthropogenic drivers of plant diversity: perspective on land use change in a dynamic cultural landscape. Biodivers. Conserv. 24, 3185-3199. https://doi.org/10.1007/ s10531-015-0949-X

Auerswald, K., Moyle, P., Seibert, S. P., Geist, J. (2019). HESS Opinions: Socio-economic and ecological trade-offs of flood management - benefits of a transdisciplinary approach. Hydrol. Earth. Syst. Sc. 23, 1035-1044. doi:10.5194/hess-23-1035-2019

Babai, D., Toth, A., Szentirmai, I., Biro, M., Mate, A., Demeter, L., Szepligeti, M., Varga, A., Molnar, A., Kun, R. \& Molnar, Z. (2015). Do conservation and agri-environmental regulations effectively support traditional small-scale farming in East-Central European cultural landscapes? Biodivers. Conserv. 24, 3305-3327. https://doi.org/10.1007/ s10531-015-0971-z

Balvanera, P., Pfisterer, A. B., Buchmann, N., He, J. S., Nakashizuka, T., Raffaelli, D. \& Schmid, B. (2006). Quantifying the evidence for biodiversity effects on ecosystem functioning and services. Ecology Letters, 9, 1146-1156. https://doi.org/10.1111/ j.1461-0248.2006.00963.x

Beltran, M., Moral, F. \& Rodríguez-Rodríguez, M. (2011). Changes in the hydrological functioning of a playa-lake complex under increasing agricultural pressures (Andalusia, Southern Spain). Water Environ. J. 26(2), 212-223 https://doi.org/10.1111/ j.1747-6593.2011.00278.x

Biró, M., Bölöni, J. \& Molnár, Z. (2018). Use of long-term data to evaluate loss and endangerment status of Natura 2000 habitats and effects of protected areas. Conserv. Biol. 32(3), 660-671 https://doi.org/10.1111/cobi.13038

Bisson, P., Rieman, B., Luce, C., Hessburg, P., Lee, D., Kershner, J., Reeves, G. H. \& Gresswell, R. (2003). Fire and aquatic ecosystems of the western USA: Current knowledge and key questions. Forest Ecol. Manag. 178, 213-229 https://doi.org/10.1016/S03781127(03)00063-X

Bixby, R. J., Cooper, S. D., Gresswell, R. E., Brown, L. E., Dahm, C. N. \& Dwire, K. A. (2015). Fire effects on aquatic ecosystems: An assessment of the current state of the science. Freshw. Sci. 34, 1340-1350 https://doi.org/10.1086/684073

Blakey, R. V., Kingsforda, R. T., Lawad, B. S. \& Stoklosa, J. (2017). Floodplain habitat is disproportionately important for bats in a large river basin. Biol. Conserv. 215, 1-10. doi:10.1016/j.biocon.2017.08.030

Blackwell, M. S. A. \& Pilgrim, E. S. (2011). Ecosystem services delivered by small-scale wetlands. Hydrolog. Sci. J. 56, 1467-1484. https://doi.org/10.1080/02626667.2011.630317

Blicharska, M., Orlikowska, E. H., Roberge, J. M. \& Grodzinska-Jurczak, M. (2016a). Contribution of social science to large scale biodiversity conservation: A review of research about the Natura 2000 network. Biol. Conserv. 199, 110-122. https://doi.org/10.1016/j.biocon.2016.05.007

Bunn, S. E. \& Arthington, A. H. (2002). Basic principles and ecological consequences of altered flow regimes for aquatic biodiversity. Environ. Manage. 30, 492-507. https://doi.org/10.1007/s00267-002-2737-0 
Carpenter, S. R., Caraco, N. F., Correll, D. L., Howarth, R. W., Sharpley, A. N. \& Smith, V. H. (1998). Nonpoint pollution of surface waters with phosphorous and nitrogen. Ecological Applications, 8, 559- 568. https://doi.org/10.1890/1051-0761(1998)008[0559:NPOSWW] 2.0.CO;2

Catford J.A., Vesk P.A., White M.D. \& Wintle B.A. (2011). Hotspots of plant invasion predicted by propagule pressure and ecosystem characteristics. Divers. Distrib. 17, 10991110. https://doi.org/10.1111/j.1472-4642.2011.00794.x

CBD (2004). Convention on Biological Diversity. Text of the Convention on Biological Diversity Retrieved December 8, 2018, from https://www.cbd.int/convention/text/

Chen, I. C., Hill, J. K., Ohlemuller, R., Roy, D. B. \& Thomas, C. D. (2011). Rapid range shifts of species associated with high levels of climate warming. Science, 333, 1024-1026. http://science.sciencemag.org/content/333/6045/1024.full

Čížková, H., Květ, J., Comín, F. A., Laiho, R., Pokorný, J. \& Pitchart, D. (2013). Actual state of European wetlands and their possible future in the context of global climate change. Aquat Sci 75, 3-26. https://doi.org/10.1007/s00027-011-0233-4

Collen, B., Whitton, F., Dyer, E. E., Baillie, J. E. M. \& Cumberlidge, N. (2014). Global patterns of freshwater species diversity, threat and endemism. Global Ecol. Biogeogr. 23, 40-51. doi:10.1111/geb.12096.

Cravotta, C. A., Goode, D. J., Bartles, M. D., Risser, D. W. \& Galeone, D. G. (2013). Surface water and groundwater interactions in an extensively mined watershed, upper Schuylkill River, Pennsylvania, USA. Hydrol. Process. 28(10), 3574-3601 https://doi.org/10.1002/hyp.9885

Creed, I. F., Bergström, A-K, Trick, C. G., Grimm, N. B., Hessen, D. O., Karlsson, J., Kidd, K. A., Kritzberg, E., McKnight, D. M., Freeman, E. C., Senar, O. E., Andersson, A., Ask, J., Berggren, M., Cherif, M., Giesler, R., Hotchkiss, E. R., Kortelainen, P., Palta, M. M., Vrede, T. \& Weyhenmeyer, G. A. (2018). Global change-driven effects on dissolved organic matter composition: Implications for food webs of northern lakes. Global Change Biol. 24(8), 3692-3714 https://doi.org/10.1111/gcb.14129

Čuda, J., Rumlerová, Z., Brůna, J., Skálová, H. \& Pyšek, P. (2017). Floods affect the abundance of invasive Impatiens glandulifera and its spread from river corridors. Divers. Distrib. 23, 342-354. https://doi.org/10.1111/ddi.12524

Cvitanovica C, McDonaldab J, Hobdayac AJ. (2016). Geographic range-scale assessment of species conservation status: A framework linking species and landscape features. $J$. Environ. Manag. 183(3):864-874 https://doi.org/10.1016/j.pecon.2018.01.001

Davis, M., Naumann, S., McFarland, K., Graf, A. \& Evans, D. (2014). Literature Review: The Ecological Effectiveness of the Natura 2000 Network. ETC/BD report to the EEA, p. 30. Retrieved December 8, 2018, from https://bd.eionet.europa.eu/Reports/ETCBDTechnical Workingpapers/The_ecological_effectiveness_of_the_Natura_2000_Network

Díez, M-A., Etxano, I. \& Garmendia, E. (2015). Evaluating Participatory Processes in Conservation Policy and Governance: Lessons from a Natura 2000 pilot case study. Environ. Policy Gov. 25(2), 125-138 https://doi.org/10.1002/eet.1667

Doulgeris, C. \& Argyroudi, A. (2018). Contribution to decision-making on establishing the maximum water level for Lake Vegoritida. Lake Reserv. Manage. https://doi.org/10.1111/lre.12249

EC, (1992). Council Directive 92/43/EEC of 21 May 1992 on the Conservation of Natural Habitats and of Wild Fauna and Flora. Consolidated Version of 13 May 2013. European 
Grzybowski M.: Principal threats to the conservation of running water habitats in the Continental Biogeographical Region of Central Europe

Commission, Brussels. Retrieved December 8, 2018, from http://eur-lex.europa.eu/legal-content/EN/TXT/PDF/?uri=CELEX: $\quad$ 01992L0043-2013 0701qid=1483906296626from $=\mathrm{EN}$

EC, (2009). Directive 2009/147/EC of the European Parliament and of the Council of 30 November 2009 on the Conservation of Wild Birds (codified Version). Consolidated Version of 13 May 2013. European Commission, Brussels. Retrieved December 8, 2018, from http://eur-lex.europa .eu/legal-content/EN/TXT/PDF/?uri=CELEX:02009L0147-2013 $0701 \&$ qid $=1484682657634$ from $=\mathrm{EN}$

EC, (2009). White paper - Adapting to climate change: towards a European framework for action. Retrieved December 8, 2018, from https://eur-lex.europa.eu/legal-content/ GA/TXT/?uri=celex:52009DC0147

EC, (2013). The Economic Benefits of the Natura 2000 Network. Synthesis Report. Publications Office of the European Union, Luxembourg, p. 76. Retrieved December 8, 2018, from http://ec.europa.eu/environment/nature/natura2000/financing/ docs/ENV-12-018_LR_Final1.pdf

EC, (2016). Natura 2000. Nature and Biodiversity Newsletter No. 40-July 2016. European Commission, Brussels. Retrieved December 8, 2018, from http://ec.europa.eu/environment/nature/info/pubs/docs/nat2000 newsl/nat40_en.pdf

EEA, (2018). Natura 2000 barometer statistics. Retrieved December 8, 2018, from https://www.eea.europa.eu/

themes/biodiversity/document-library/natura-2000/natura-2000-network-statistics/natura-20 00-barometer-statistics/statistics/barometer-statistics\#tab-based-on-data.

Eigenbrod, F., Hecnar, S. J. \& Fahrig, L. (2009). Quantifying the roadeffect zone: threshold effects of a motorway on anuran populations in Ontario. Ecology and Society, 14(1), 24. https://eprints.soton.ac.uk/id/eprint/181359

Eionet, (2018a). Reference Portal for Natura 2000. Retrieved December 8, 2018, from https://bd.eionet.europa.eu/activities/Natura_2000/reference_portal

Eionet, (2018b). Reporting under Article 17 of the Habitats Directive. Retrieved December 8, 2018, from https://bd.eionet.europa.eu/activities/Reporting/Article_17

Ellison, C. A., Skinner, Q. D. \& Hicks, L. S. (2009). Assessment of best management practice effects on rangeland stream water quality using multivariate statistical techniques. Rangeland Ecol. Manag. 62, 371-386 https://doi.org/10.2111/08-026.1

Estreguil, Ch., Caudullo, J. \& de Rigo, D. (2014). A proposal for an integrated modelling framework to characterise habitat pattern. Environ. Modell. Softw. 52, 176-191. https://doi.org/10.1016/j.envsoft.2013.10.011

Fernández-Llamazares, A., Díaz-Reviriego, I., Luz, A. C., Cabeza, M., Pyhälä, A. \& Reyes-García, V. (2015). Rapid ecosystem change challenges the adaptive capacity of Local Environmental Knowledge. Global Environ. Chang. 31, 272-284. doi: 10.1016/j.gloenvcha.2015.02.001

Filoso, S., Bezerra, M. O., Weiss, K. C. B. \& Palmer, M. A. (2017). Impacts of forest restoration on water yield: A systematic review. PLoS ONE 12, e0183210. https://doi.org/10.1371/journal.pone.0183210

Foley, J. A., DeFries, R., Asner, G. P., Barford, C., Bonan, G., Carpenter, S. R., Chapin, F. S., Coe, M. T., Daily, G.C., Gibbs, H.K., Helkowski, J. H., Holloway, T., Howard, E.A., Kucharik, C. J., Monfreda, C., Patz, J.A., Prentice, I. C., Ramankutty, N. \& Snyder, P. K. 
(2005). Global consequences of land use. Science, 22, 570-574. http://doi.org/ 10.1126/science. 1111772

Folke, C., Carpenter, S., Walker, B., Scheffer, M., Elmqvist, T., Gunderson, L. \& Holling, C. S. (2004). Regime Shifts, Resilience, and Biodiversity in Ecosystem Management. Annu. Rev. Ecol. Evol. S. 35, 557-581 https://doi.org/10.1146/annurev.ecolsys.35.021103.105711

Francis, R. A., Chadwick, M. A. \& Turbelin, A. J. (2019). An overview of non-native species invasions in urban river corridors. River Basin. River Res. Appl. https://doi.org/10.1002/rra.3513

Franklin, H. M,, Robinson, B. H. \& Dickinson, N. M. (2019). Plants for nitrogen management in riparian zones: A proposed trait-based framework to select effective species. Ecol. Manag. Restor. https://doi.org/10.1111/emr.12380

Freudenberger, L., Hobson, P. R., Rupic, S., Peer, G., Schluck, M., Sauermann, J., Kreft, S., Selva, N. \& Ibisch, P. L. (2013). Spatial road disturbance index (SPROADI) for conservation planning: a novel landscape index, demonstrated for the State of Brandenburg, Germany. Landscape Ecol. 28, 1353-1369. https://doi.org/10.1007/s10980-013-9887-8

Friberg, N., Rebsdorf, A. \& Larsen, S. (1998). Effects of afforestation on acidity and invertebrates in Danish streams and implications for freshwater communities in Denmark. Water Air Soil Poll. 101, 235-256 https://doi.org/10.1023/A:1004949203686

Garniel, A. (2000). Schutzkonzept für gefährdete Wasserpflanzen der Fließgewässer und Gräben Schleswig-Holsteins. Teil C. Gräben. Landesamt für Natur und Umwelt Schleswig-Holstein, Kiel.

GDEP, (2017). General Directorate for Environmental Protection in Poland. Platforma informacyjno-komunikacyjna. Retrieved December 8, 2018, from http://pzo.gdos.gov.pl

GDEP, (2018). General Directorate for Environmental Protection in Poland. Standard Data Form. Retrieved December 8, 2018, from http://natura2000.gdos.gov.pl/wyszukiwarka-n2k

Genseberger, M., Noordhuis, R., Thiange, C. \& Boderie, P. (2016). Practical measures for improving the ecological state of Lake Marken using in-depth system knowledge. Lake Reserv. Manage. 21(1).56-64 https://doi.org/10.1111//re.12122

Gerlak, A. K. (2004), Strengthening river basin institutions: The Global Environment Facility and the Danube River Basin. Water Resour. Res. 40(8) https://doi.org/10.1029/2003wr002936

GIEP, (2018). General Inspection of Environmental Protection in Poland. Monitoring of species and natural habitats. Retrieved December 8, 2018, from http://siedliska.gios.gov.pl/pl/

Gillson, L., Whitlock, C. \& Humphrey, G. (2019). Resilience and fire management in the Anthropocene. Ecology and Society 24(3), 14. https://doi.org/10.5751/ES-11022-240314

Glińska-Lewczuk, K. (2005). Oxbow lakes as biogeochemical filters for nutrient outflow from agricultural areas. Dynamics and biogeochemistry of river corridors and wetlands. IAHS 294, 55-69.

Gold, A. C., Thompson, S. P. \& Piehler, M. F. (2019). The effects of urbanization and retention-based stormwater management on coastal plain stream nutrient export. Water Resour. Res. https://doi.org/10.1029/2019WR024769

Goode, J. R., Luce, C. H. \& Buffington, J. M. (2012). Enhanced sediment delivery in a changing climate in semi-arid mountain basins: Implications for water resource management and aquatic habitat in the northern Rocky Mountains. Geomorphology 139, 1-15 
Grzybowski M.: Principal threats to the conservation of running water habitats in the Continental Biogeographical Region of Central Europe

https://doi.org/10.1016/j.geomorph.2011.06.021

Grzybowski, M. (2014). Determinants of the diversity of macrophytes in natural lakes affected by land use in the catchment, water chemistry and morphometry lakes. J. Elementol. 19(2), 401-422. http://doi.org/10.5601/jelem.2014.19.1.447

Grzybowski, M., Glińska-Lewczuk, K. (2019). Principal threats to the conservation of freshwater habitats in the continental biogeographical region of Central Europe. Biodivers. Conserv. 28, 4065-4097. https://doi.org/10.1007/s10531-019-01865-x

Gustafsson, L., Felton, A., Felton, A.M., Brunet, J., Caruso, A., Hjältén, J., Lindbladh, M., Ranius, T., Roberge, J. M. \& Weslien, J. (2015). Natural versus national boundaries: the importance of considering biogeographical patterns in forest conservation policy. Conservation Letters, 8, 50-57. https://doi.org/10.1111/conl.12087

Güsewell, S. \& Le Nédic, C. (2004). Effects of winter mowing on vegetation succession in a lakeshore fen. Appl. Veg. Sci. 7(1), 41-48. https://doi.org/10.1111/j.1654-109X. 2004.tb00594.x

Hajdukiewicz, H., Wyzga, B., Zawiejska, J., Amirowicz, A., Oglęcki, P. \& Radecki-Pawlik, A. (2017). Assessment of river hydromorphological quality for restoration purposes: an example of the application of RHQ method to a Polish Carpathian river. Acta Geophys. 65, 423-440. doi:10.1007/s11600-017-0044-7

Harrison, P. A., Vandewalle, M., Sykes, M.T., Berry, P. M., Bugter, R., de Bello, F., Feld, C.K., Grandin, U., Harrington, R., Haslett, J.R., Jongman, R. H. G., Luck, G. W., da Silva, P. M., Moora, M., Settele, J., Sousa, J. P. \& Zobel, M. (2010). Identifying and prioritizing services in European terrestrial and freshwater ecosystems. Biodivers. Conserv. 19, 27912821. https://doi.org/10.1007/s10531-010-9789-X

Harvey, G. L., Henshaw, A. J., Brasington, J. \& England, J. (2019). Burrowing invasive species: an unquantified erosion risk at the aquatic-terrestrial interface. Rev. Geophys. https://doi.org/10.1029/2018RG000635

Havel, J. E., Kovalenko, K. E., Thomaz, S. M., Amalfitano, S., \&Kats, L. B. (2015). Aquatic invasive species: Challenges for the future. Hydrobiologia 750(1):147-170. doi:10.1007/s10750-014-2166-0

Hefting, M. M., van den Heuvel, R.N., Verhoeven, J. T. A. (2013). Wetlands in agricultural landscapes for nitrogen attenuation and biodiversity enhancement: opportunities and limitations. Ecol. Eng. 56, 5-13. https://doi.org/10.1016/j.ecoleng.2012.05.001

Hein, T., Schwarz, U., Habersack, H., Nichersu, J., Preiner, S., Willby, N., Weigelhofer, G., 2016. Current status and restoration options for floodplains along the Danube River. Sci. Total Environ. 543, 778-790. https://doi.org/10.1016/j.scitotenv.2015.09.073

Hein, T., Funk, A., Pletterbauer, F., Graf, W., Zsuffa, I., Haidvogl, G., Schinegger, R. \& Weigelhofer, G. (2018). Management challenges related to long-term ecological impacts, complex stressor interactions, and different assessment approaches in the Danube River Basin. River Res. Appl. 35(5), 500-509 https://doi.org/10.1002/rra.3243

Herbert, M. E., Mcintyre, P. B., Doran, P. J., Allan, J. D. \& Abell, R. (2010). Terrestrial reserve networks do not adequately represent aquatic ecosystems. Conserv. Biol. 24, 10021011 https://doi.org/10.1111/j.1523-1739.2010.01460.x

Hermoso, V., Cattarino, L., Linke, S. \& Kennard, M. J. (2018). Catchment zoning to enhance co-benefits and minimize trade-offs between ecosystem services and freshwater biodiversity conservation. Aquat. Conserv. 28, 1004-1014 https://doi.org/10.1002/aqc.2891. 
Hermoso, V., Clavero, M., Villero, D. \& Brotons, L. (2017). EU's conservation efforts need more strategic investment to meet continental commitments. Conservation Letters, 10(2), 231-23. https://doi.org/10.1111/conl.12248

Hobbs, R. J. \& Huenneke, L. F. (1992). Disturbance, Diversity, and Invasion: Implications for Conservation. Conserv. Biol., 6, 324-337. https://doi.org/10.1046/j.1523-1739. 1992.06030324.X

IPBES. (2019). Summary for policymakers of the global assessment report on biodiversity and ecosystem services of the Intergovernmental Science-Policy Platform on Biodiversity and Ecosystem Services. Díaz, S., Settele, J., Brondizio, E. S., Ngo, H. T., Guèze, M., Agard, J., Arneth, A., Balvanera, P., Brauman, K. A., Butchart, S. H. M., Chan, K. M. A., Garibaldi, L. A., Ichii, K., Liu, J., Subramanian, S. M., Midgley, G. F., Miloslavich, P., Molnár, Z., Obura, D., Pfaff, A., Polasky, D., Purvis, A., Razzaque, J., Reyers, B., Chowdhury, R., Shin, Y. J., Visseren-Hamakers, I. J., Willis, K. J. \& Zayas, C. N. (eds.). IPBES secretariat, Bonn, Germany.

Janssen, J. A. M., Rodwell, J. S., Garcia Criado, M., Gubbay, S., Haynes, T., Nieto, A., Sanders, N., Landucci, F., Loidi, J., Ssymank, A., Tahvanainen, T., Valderrabano, M., Acosta, A., Aronsson, M., Arts, G., Attorre, F., Bergmeier, E., Bijlsma, R-J, Bioret, F., Bita-Nicole, C., Biurrun, I., Calix, M., Capelo, J., Carni, M., Chytry, M., Dengler, J., Dimopoulos, P., Essl, F., Gardjfell, H., Gigante, D., Giusso del Galdo, G., Hajek, M., Jansen, F., Kapfer, J., Mickolajczak, A., Molina, J.A., Molnár, Z., Paternoster, D., Piernik, A., Poulin, B., Renaux, B., Schaminee, J. H. J., Sumberova, K., Toivonen, H., Tonteri, T., Tsiripidis, I., Tzonev, R. \& Valachovic, M. (2016). European Red List of Habitats, Part 2: Terrestrial and freshwater habitats. EU, p 44. https://doi.org/10.2779/091372

Kapustka, L. A., Bowers, K., Isanhart, J., Martinez-Garza, C., Finger, S., Stahl, R. G. \& Stauber, J. (2015). Coordinating ecological restoration options analysis and risk assessment to improve environmental outcomes. Integrated Environ. Assess. Manag. 12(2), 253-263 https://doi.org/10.1002/ieam.1673

Keller, R. P., Geist, J., Jeschke, J. M., Kühn, I. (2011). Invasive species in Europe: Ecology, status, and policy. Environ. Sci. Eur. 23(1), 23. doi:10.1186/2190-4715-23-23

Kingsford, R. T. (2011). Conservation management of rivers and wetlands under climate change - a synthesis. Mar. Freshwater Res. 62, 217-222 https://doi.org/10.1071/MF11029

Kreft, H. \& Jetz, W. (2010). A framework for delineating biogeographical regions based on species distributions. J. Biogeogr. 37(11), 2029 - 2053. https://doi.org/10.1111/j.13652699.2010.02375.x

Lambdon, P. W., Pyšek, P., Basnou, C., Hejda, M., Arianoutsou, M., Essl, F., Jarošík, V., Pergl, J., Winter, M., Anastasiu, P., Andriopoulos, P., Bazos, I., Brundu, G., Celesti-Grapow, L., Chassot, P., Delipetrou, P., Josefsson, M., Kark, S., Klotz, S., Kokkoris, Y., Kühn, I., Marchante, H., Perglová, I., Pino, J., Vilà, M., Zikos, A., Roy, David \& Hulme, P. E. (2008). Alien flora of Europe: species diversity, temporal trends, geographical patterns and research needs. Preslia, 80 (2), 101-149.

Lemly,, A. D., Kingsford, R. T. \& Thompson, J. R. (2000). Irrigated Agriculture and Wildlife Conservation: Conflict on a Global Scale. Environ. Manag. 25, 485-512. https://doi.org/10.1007/s002679910039

Leyssen, A., Denys, L., Schneiders, A. \& Mouton, A. M. (2014). Distribution and environmental requirements of stream habitat with Ranunculion fluitantis and CallitrichoBatrachion vegetation in lower Belgium (Flanders). Aquat. Conserv. 24(5), 601-622 https://doi.org/10.1002/aqc.2438 
Grzybowski M.: Principal threats to the conservation of running water habitats in the Continental Biogeographical Region of Central Europe

Lopoukhine, N., Crawhall, N., Dudley, N., Figgis, P., Karibuhoye, C., Laffoley, D., Londoño, J. M., MacKinnon, K. \& Sandwith, T. (2012). Protected areas: providing natural solutions to $21 \mathrm{st}$ Century challenges. S.A.P.I.EN.S. 5(2), 117-131. http://journals.openedition.org/sapiens/

Lepers, E., Lambin, E. F., Janetos, A. C., DeFries, R., Achard, F., Ramankutty, N. \& Scholes, R. J. (2005). A synthesis of information on rapid land-cover change for the period 1981-2000. BioScience, 55, 115-124. https://doi.org/10.1641/0006-3568(2005)055 [0115:ASOIOR]2.0.CO;2

Lepš, J. \& Šmilauer, P. (2014). Multivariate Analysis of Ecological Data using CANOCO 5. Cambridge: Cambridge University Press. https://doi.org/10.1017/CBO9781139627061

Loucks, D. P. \& van Beek, E. (2017), Water Resources Planning and Management: An Overview. In: Water Resource Systems Planning and Management. Springer, Cham. https://doi.org/10.1007/978-3-319-44234-1_1

Lososová, Z., Chytrý, M., Kühn, I., Hájek, O., Horáková, V., Pyšek, P. \& Tichý, L. (2006). Patterns of plant traits in annual vegetation of man-made habitats in central Europe. Perspect. Plant. Ecol. 8, 69-81. https://doi.org/10.1016/j.ppees.2006.07.001

Maffi, L. \& Woodley, E. (2010). Biocultural diversity conservation. A Global Sourcebook, Earthscan.

Mandák, B., Pyšek, P. \& Bímová, K. (2004). History of the invasion and distribution of Reynoutria taxa in the Czech Republic: a hybrid spreading faster than its parents. Preslia 76, 15-64.

Meier, M., Gerlach, R., Schirmel, J. \& Buhk, C. (2017). Plant diversity in a water-meadow landscape: the role of irrigation ditches. Plant Ecol., 218, 971-981. https://doi.org/10.1007/s11258-017-0744-8

Millennium Ecosystem Assessment [MEA]. (2005). Ecosystems and Human Wellbeing: Synthesis. Washington (DC) Island Press.

Mitsch, W. J., Zhang, L., Stefanik, K. C., Nahlik, A. M., Anderson, C. J., Bernal, B., Hernandez, M. \& Song, K. (2012). Creating wetlands: primary succession, water quality changes, and self-design over 15 years. BioScience, 62, 237-250. https://doi.org/10.1525/bio.2012.62.3.5

Molina-Navarro, E., Andersen, H. E., Nielsen, A., Thodsen, H. \& Trolle, D. (2018). Quantifying the combined effects of land use and climate changes onstream flow and nutrient loads: A modelling approach in the Odense Fjord catchment (Denmark). Sci. Total Environ. 621, 253-264. https://doi.org/10.1016/j.scitotenv.2017.11.251

Morelli, T. L., Daly, C., Dobrowski, S.Z., Dulen, D. M., Ebersole, J.L., Jackson, S. T., Lundquist, J. D., Millar, C. I., Maher, S. P., Monahan, W. B., Nydick, K. R., Redmond, K. T., Sawyer, S. C., Stock, S. \& Beissinger, S. R. (2016). Managing Climate Change Refugia for Climate Adaptation. PLoS ONE. 12(1): e0169725.36. Retrieved January 5, 2018, from https://doi.org/10.1371/journal. pone.0169725

Mróz, W. (2017). Monitoring of natural habitats. Methodological guide. Introduction. Library of Environmental Monitoring. Inspection of Environmental Protection. Warsaw.

Müller, I. B., Buhk, C., Lange, D., Entling, M.H. \& Schirmel, J. (2016). Contrasting effects of irrigation and fertilization on plant diversity in hay meadows. Basic Appl. Ecol. 17, 576585. http://dx.doi.org/10.1016/j.baae.2016.04.008

Myronidis, D., Stathis, D. \& Sapountzis, M. (2016). Post-Evaluation of Flood Hazards 
Induced by Former Artificial Interventions along a Coastal Mediterranean Settlement, Journal of Hydrologic Engineering, 21(10), 05016022

Naiman, R. \& Decamps, H. (1997). The ecology of interfaces: Riparian zones. Annu Rev. Ecol. Evol. S. 28, 621-658 https://doi.org/ 10.1146/annurev.ecolsys.28.1.621

Orlikowska, E. H., Roberge, J. M., Blicharska, M. \& Mikusiński, G. (2016). Gaps in ecological research on the world's largest internationally coordinated network of protected areas: A review of Natura 2000. Biol. Conserv. 200, 216-227. https://doi.org/10.1016/j.biocon.2016.06.015

Ortmann-Ajkai, A., Csicsek, G., Hollós, R., Magyaros, V., Wágner, L. \& Lóczy, D. (2018). Twenty-Years' Changes of Wetland Vegetation: Effects of Floodplain-Level Threats. Wetlands, 38: 591. https://doi.org/10.1007/s13157-018-1002-0

Ostrofsky, M. L. (1978). Trophic Changes in Reservoirs; An Hypothesis Using Phosphorus Budget Models. International Review of Hydrobiology 63(4), 481-499 https://doi.org/10.1002/iroh.19780630403

Pallemearts, M., Parker, C. N., Shukla, P. R. \& Van Schaik, L. G. (2005). The Greenland dialogue on climate change: a policy discussion paper.

Parris, K. M. \& Schneider, A. (2009). Impacts of traffic noise and traffic volume on birds of roadside habitats. Ecology and Society, 14(1), 29. https://doi.org/10.5751/ES-02761-140129

Pataki, B., Zsuffa, I. \& Hunyady, A. (2013). Vulnerability assessment for supporting the revitalization of river floodplains. Environ. Sci. Policy 34, 69-78. https://doi.org/10.1016/j.envsci.2012.08.010

Percic, V., Horvatic, J., Has-Schön, E. \& Bogut, I. (2009). Changes in N and P limitation induced by water level fluctuations in Nature Park Kopacki Rit (Croatia): nutrient enrichment bioassay. Aquat. Ecol. 43, 27-36. https://doi.org/10.1007/s10452-007-9156-5

Pilliod, D., Bury, R., Hyde, E., Pearl, C. \& Corn, P. (2003). Fire and amphibians in North America. Forest Ecol. Manag. 178, 163-181 https://doi.org/10.1016/S03781127(03)00060-4

Popescu, V. D., Rozylowicz, L., Niculae, I. M., Cucu, A. L. \& Hartel, T. (2014). Species, habitats, society: an evaluation of research supporting EU's Natura 2000 network. PLoS One. 9, 13-22. https://doi.org/10.1371/journal.pone.0113648

Pretty, J., Adams, B., Berkes, F., de Athayde, S., Dudley, N., Hunn, E., Maffi, L., Milton, K., Rapport, D., Robbins, P., Sterling, E., Stolton, S., Tsing, A., Vintinnerk, E. \& Pilgrim, S. (2009). The intersections of biological diversity and cultural diversity: towards integration. Conservation and Society, 7, 100-112. http://doi.org/10.4103/0972-4923.58642

Rattisab, L., Dobrovolskic, R., Talebid, M. \& Loyolae, R. (2018). Geographic range-scale assessment of species conservation status: A framework linking species and landscape features. PECON. 16 (2), 97-104. http://doi.org/10.1016/j.pecon.2018.01.001

RDEP, (2018). Regional Directorate for Environmental Protection in Poland. Retrieved December 8, 2018, from bialystok.rdos.gov.pl; bydgoszcz.rdos.gov.pl; gdansk.rdos.gov.pl; gorzow.rdos.gov.pl; katowice.rdos.gov.pl, kielce.rdos.gov.pl, krakow.rdos.gov.pl, lublin.rdos.gov.pl; lodz.rdos.gov.pl, olsztyn.rdos.gov.pl, opole.rdos.gov.pl, poznan.rdos.gov.pl, rzeszow.rdos.gov.pl, szczecin.rdos.gov.pl, warszawa.rdos.gov.pl, wroclaw.rdos.gov.pl

Revenga, C., Campbell, I., Abell, R., de Villiers, P. \& Bryer, M. (2005). Prospects for monitoring freshwater ecosystems towards the 2010 targets. Philosophical Transactions of The Royal Society B Biological Sciences, 360, 397-413. https://doi.org/ 
Grzybowski M.: Principal threats to the conservation of running water habitats in the Continental Biogeographical Region of Central Europe

\subsection{8/rstb.2004.1595}

Richardson, D. M., Holmes, P.M., Esler, K. J., Galatowitsch, S. M., Stromberg, J. C., Kirkman, S. P., Pyšek, P. \& Hobbs, R. J. (2007). Riparian vegetation: degradation, alien plant invasions, and restoration prospects. Divers. Distrib. 13, 126-139. https://doi.org/10.1111/j.1366-9516.2006.00314.x

Rodrigues, A. S. L., Andelman, S. J., Bakarr, M. I., Boitani, L., Brooks, T. M., Cowling, R. M., Fishpool, L. D. C., da Fonseca, G. A. B., Gaston, K. J., Hoffmann, M., Long, J. S., Marquet, P. A., Pilgrim, J. D., Pressey, R. L., Schipper, J., Sechrest, W., Stuart, S. N., Underhill, L. G., Waller, R. W., Watts, M. E. J. \& Yan, X. (2004). Effectiveness of the global protected area network in representing species diversity. Nature, 428, 640-643. http://doi.org/10.1038/nature02422

Roni, P., Hanson, K. \& Beechie, T. (2008). Global review of the physical and biological effectiveness of stream habitat rehabilitation techniques. N. Am. J. Fish. Manage. 28, 856890 https://doi.org/10.1577/M06-169.1

Royal Society (2017). Climate Updates: What have we learnt since the IPCC 35 th Assessment Report? https://royalsociety.org/topics-policy/publications/2017/climateupdates/.

Salmi, P., Auvinen, H., Jurvelius, J. \& Sipponen, M. (2004). Finnish lake fisheries and conservation of biodiversity: coexistence or conflict? Fish. Manag. Ecol. 7(1-2), 127-138 doi:10.1046/j.1365-2400.2000.00183.x

Sandom, C. J., Hughes, J. \& Macdonald, D. W. (2013). Rewilding the Scottish highlands: do wild boar, sus scrofa, use a suitable foraging strategy to be effective ecosystem engineers? Restor. Ecol. 21, 336-343. https://doi.org/10.1111/j.1526-100X.2012.00903.x

Sardain, A., Sardain, E., Leung, B. (2019). Global forecasts of shipping traffic and biological invasions to 2050. Nature Sustainability, doi:10.1038/s41893-019-0245-y

Sheridan, C., Akcil, A., Kappelmeyer, U. \& Moodley, I. (2018). A Review on the Use of Constructed Wetlands for the Treatment of Acid Mine Drainage. Constructed Wetlands for Industrial Wastewater Treatment 249-262 https://doi.org/10.1002/9781119268376.ch12

Schnitzler, A. E., Hale, B. W. \& Alsum, E. (2005). Biodiversity of floodplain forests in Europe and eastern North America: a comparative study of the Rhine and Mississipi Valleys. Biodivers. Conserv. 14, 97-117. http://http:/doi.org/10.1007/s10531-005-4056-2

Schröter, D., Cramer, W., Leemans, R., Prentice, I. C., Araújo, M. B., Arnell, N. W., Bondeau, A., Bugmann, H., Carter, T. R., Gracia, C. A., de la Vega-Leinert, A. C., Erhard, M., Ewert, F., Glendining, M., House, J. I., Kankaanpää, S., Klein, R. J., Lavorel, S., Lindner, M., Metzger, M. J., Meyer, J., Mitchell, T. D., Reginster, I., Rounsevell, M., Sabaté, S., Sitch, S., Smith, B., Smith, J., Smith, P., Sykes, M. T., Thonicke, K., Thuiller, W., Tuck, G., Zaehle, S. \& Zierl, B. (2005). Ecosystem service supply and vulnerability to global change in Europe. Science 310(5752), 1333-7. https://doi.org/10.1126/science.1115233

Secretariat of the Convention on Biological Diversity (2008). Protected Areas in Today's World: Their. Values and Benefits for the Welfare of the Planet. Montreal, Technical Series no. 36. Retrieved February 10, 2019, from https://www.cbd.int/doc/publications/ cbd-ts-36-en.pdf

Selva, N., Kreft, S., Kati, V., Schluck, M., Jonsson, B., Mihok, B., Okarma, H. \& Ibisch, P. L. (2011). Roadless and low-traffic areas as conservation targets in Europe. Environ Manage. 48(5), 865-877. http://doi.org/10.1007/s00267-011-9751-z 
Schurr, F. M., Spiegel, O., Steinitz, O., Trakhtenbrot, A., Tsoar, A. \& Nathan, R. (2009). Long-Distance Seed Dispersal. Annu. Rev. Plant. Biol. 38, 204-237. doi:10.1002/9781444314557.ch6

Sievers, M., Hale, R. \& Morrongiello, J. R. (2017). Do trout respond to riparian change? A meta-analysis with implications for restoration and management. Freshwater Biol. 62, 445457 https://doi.org/10.1111/fwb.12888

Stępniewska, M., Zwierzchowska, I. \& Mizgajski, A. (2018). Capability of the Polish legal system to introduce the ecosystem services approach into environmental management. Ecosystem Services, 29, 271-281. http://doi.org/10.1016/j.ecoser.2017.02.025

Strayer, D. L. \& Dudgeon, D. (2010). Freshwater biodiversity conservation: Recent progress and future challenges. J. N. Am Benthol. Soc. 29, 344-358. https://doi.org/10.1899/08-171.1

ter Braak, C. J. F. \& Smilauer, P. (1998). Canoco Reference Manual and User's Guide to Canoco forWindows: Software for Canonical Community Ordination, Version 4. New York, Microcomputer Power, Ithaca.

ter Braak, C. J. F. \& Verdonschot, P. F. M. (1995). Canonical correspondence analysis and related multivariate methods in aquatic ecology. Aquat Sci 57, 255-289. https://doi.org/10.1007/BF00877430

Thieme, M. L., Sindorf, N., Higgins, J., Abell, R., Takats, J. A., Naidoo, R. \& Barnett, A. (2016). Freshwater conservation potential of protected areas in the Tennessee and Cumberland River Basins, USA. Aquat. Conserv. 26, 60-77 https://doi.org/10.1002/aqc.2644

Tierney, D., Kelly-Quinn, M. \& Bracken, J. (1998). The faunal communities of upland streams in the eastern region of Ireland with reference to afforestation impacts. Hydrobiologia 389, 115-130 https://doi.org/10.1023/A:1003510016292

Tockner, K., Stanford, J. A. (2002). Riverine floodplains: present state and future trends. Environ. Conserv. 29, 308-330. http://doi.org/10.1017/S037689290200022X

Toporowska, M., Ferencz, B. \& Dawidek, J. (2018). Impact of lake-catchment processes on phytoplankton community structure in temperate shallow lakes. Ecohydrology e2017. https://doi.org/10.1002/eco.2017

Underhill, J. E. \& Angold, P. G. (2000). Effects of roads on wildlife in an intensively modified landscape. Environ. Rev. 8, 21-39. doi:10.1139/a00-003

UN (2017). Department of Economic and Social Affairs (2017). Sustainable development goals report 2017. New York, USA: United Nations.

UNEP/IPBES (2010). United Nations Environment Programme. Report of the third ad hoc intergovernmental and multi-stakeholder meeting on an intergovernmental science-policy platformon biodiversity and ecosystem services. UNEP/IPBES/3/3

UNEP-WCMC, IUCN (2016). Protected Planet Report 2016. UNEP-WCMC and IUCN, Cambridge UK and Gland, Switzerland.

Ustaoglu, E. \& Williams, B. (2017). Determinants of Urban Expansion and Agricultural Land Conversion in 25 EU Countries. Environ Manage. 60, 717-746. http://doi.org/10.1007/s00267-017-0908-2

Yeung, A. C. Y., Lecerf, A. \& Richardson, J. S. (2017). Assessing the longterm ecological effects of riparian management practices on headwater streams in a coastal temperate rainforest. Forest. Ecol. Manag. 384,100-109 https://doi.org/10.1016/j.foreco.2016.10.044 
Grzybowski M.: Principal threats to the conservation of running water habitats in the Continental Biogeographical Region of Central Europe

Van Strien, A. J., Van der Burg, T., Rip, W. T. M. \& Strucker, R. C. W. (1991). Effects of mechanical ditch management on the vegetation of ditch banks in Dutch peat areas. $J$ Appl Ecol. 28, 501-513. http://doi.org/10.2307/2404564

Vardarman, J., Berchová-Bímová, K. \& Pěknicová, J. (2018). The role of protected area zoning in invasive plant management. Biodivers. Conserv. 27, 1811-1829. https://doi.org/10.1007/s10531-018-1508-z

Von Der Lippe, M. \& Kowarik, I. (2007). Long-distance dispersal of plants by vehicles as a driver of plant invasions. Conserv. Biol., 21, 986-996. https://doi.org/10.1111/j.1523-1739.2007.00722.x

Vörösmarty, C. J., McIntyre, P. B., Gessner, M. O., Dudgeon, D., Prusevich, A., Green, P. S., Glidden, S., Bunn, S. E., Sullivan, C. A., Reidy Liermann, C. \& Davies, P. M. (2010). Global threats to human water security and river biodiversity. Nature, 467, 555-561. https://doi.org/10.1038/nature09440

Vaughn, C. (2010). Biodiversity losses and ecosystem function in freshwaters: Emerging conclusions and research directions. BioScience 60, 25-35. doi:10.1525/bio.2010.60.1.7

Voulvoulis N., Arpon K. D. \& Giakoumis T. (2017). The EU Water Framework Directive: From great expectations to problems with implementation. Sci. Total Environ. 575, 358-366. https://doi.org/10.1016/j.scitotenv.2016.09.228

Ward, J. V. \& Stanford, J. A. (1995). Ecological connectivity in alluvial river ecosystems and its disruption by flow regulation. River Res. Appl. 11, 105-119. https://doi.org/10.1002/rrr.3450110109

Wilk-Woźniak, E., Walusiak, E., Burchardt, L., Cerbin, S., Chmura, D., Gąbka, M., Glińska-Lewczuk, K., Gołdyn, R., Grabowska, M., Karpowicz, M., Klimaszyk, M., Kołodziejczyk, A., Kokociński, M., Kraska, M., Król, W., Kuszyńska-Kippen, N., Ligeza, S., Messyasz, B., Nagegast, B., Ozimek, T., Paczuska, B. M., Pelechaty, M., Pęczuła, W., Pietryka, W., Piotrowicz, R., Pociecha, A., Pukacz, A., Richter, D. \& Żbikowski, J. (2019). Effects of the environs of waterbodies on aquatic plants in oxbow lakes (habitat 3150). Ecol. Indic. 98, 736-742. doi:10.1016/j.ecolind.2018.11.025

Worku, H. (2017). Environmental and socioeconomic impacts of cobblestone quarries in Addis Ababa and implication for resource use efficiency, environmental quality, and sustainability of land after-use. Environmental Quality Management 27(2), 41-61 https://doi.org/10.1002/tqem.21524

Wuebbles, D. J., Easterling D. R, Hayhoe K., Knutson T., Kopp R. E., Kossin J. P., Kunkel K. E., LeGrande A. N., Mears C., Sweet W. V., Taylor P. C., Vose R. S. \& Wehner M. F. (2017). Our globally changing climate. Climate Science Special Report: Fourth National Climate Assessment, Volume I. In. D. J. Wuebbles, D. W. Fahey, K. A. Dokken, D. J. Hibbard, B. C. Stewart \& T. K., Maycock (Eds.), U.S. Global Change Research Program (pp. 35-72). USA: Washington, DC. http://doi.org/10.7930/J08S4N35

WWAP, UN-Water (2018). The United Nations world water development report 2018: Nature-based solutions for water. Paris, France: UNESCO. Retrieved August 20, 2019, from http://unesdoc.unesco.org/images/0026/002614/261424e.pdf

WWF (2018). Living Planet Report - 2018: Aiming Higher. Grooten M. and Almond R.E.A (Eds) WWF, Gland, Switzerland.

Zedková, B., Rádková, V., Bojková, J., Soldán, T. \& Zahrádková, S. (2014). Mayflies (Ephemeroptera) as indicators of environmental changes in the past five decades: a case 
study from the Morava and Odra River Basins (Czech Republic). Aquat. Conserv. 25(5), 622-638 https://doi.org/10.1002/aqc.2529

Zedler, J. B. \& Kercher, S. (2004). Causes and consequences of invasive plants in wetlands: Opportunities, opportunists, and outcomes. Crit. Rev. Plant. Sci. 23(5), 431-452. doi:10.1080/07352680490514673

Zorilla-Miras, P., Palomo, I., Gomes-Baggenthun, E., Martin-Lopez, B., Lomas, P. L. \& Montes, P. (2014). Effects of land-use change on wetland ecosystem services: a case study in the Donana marshes (SWSpain). Landscape Urban Plan. 122, 60-174. https://doi.org/10.1016/j.landurbplan.2013.09.013 